\title{
YAPAY ZEKÂ VE İDARE HUKUKU \\ (BUGÜNDEN GELECEĞE YÖNELİK BİR DEĞERLENDİRME)
}

ARTIFICIAL INTELLIGENCE AND ADMINISTRATIVE LAW

(AN ASSESSMENT FROM TODAY TO THE FUTURE)

Hakemli Makale

Mutlu KAĞITCIOĞLU*

\section{İÇiNDEKILER}

GİRISs 120

I. İDARE HUKUKU VE YAPAY ZEKÂ KAVRAMI. 121

II. İDARE HUKUKUNUN YAPAY ZEKÂ İLE İLIŞKISINDDEKİ ÖNCELIKLII HUKUKİ KONULAR

A. Yapay Zekânın Hukuki Statüsü: Hukuk İçin Bir Meydan Okuma 127

1. Yapay Zekânın Hukuki Statüsünün Belirlenmesindeki Dinamikler: Hukuki Kişilik Tartışmaları ve Gelişen Yapay Zekâ Türleri 128

B. Yapay Zekâ ve Algoritma Teknolojisinin Şimdiden Düşündürdükleri ve Hukukun İçinde Bulunduğu İkilem 136

III. YAPAY ZEKÂNIN IDARE HUKUKU BOYUTU. 140

A. Yapay Zekânın, Organik ve Fonksiyonel Anlamda İdare Üzerindeki Etkileri. 140

1. Yapay Zekâ ve Organik Anlamda İdare Üzerinde Etkileri........................................................ 140

2. Yapay Zekâ ve Fonksiyonel Anlamda İdare Üzerinde Etkileri ............................................... 143

a. İdarenin Düzenleme ve Denetleme Faaliyetleri ile Yapay Zekânın Kesişimi......................... 143

b. İdari Usul ve İdari İşlem Açısından Yapay Zekânın Rolü.................................................... 147

B. Yapay Zekânın, İdarenin Sorumluluğuna Getireceği Yaklaşımlar. 149

DOI: $10.32957 /$ hacettepehdf. 874993

Makalenin Geliş Tarihi: 05.02.2021

Makalenin Kabul Tarihi: 16.06.2021

* Doç. Dr., Tekirdağ Namık Kemal Üniversitesi Hukuk Fakültesi, İdare Hukuku Ana Bilim Dalı Öğretim Üyesi, E-posta: mutlukagitcioglu@gmail.com

ORCID: 0000-0001-8032-0976

Bu makale çalışması Hacettepe Üniversitesi Hukuk Fakültesi Dergisi Araştırma ve Yayın Etiği kurallarına uyularak hazırlanmıştır. 
SONUÇ

KAYNAKÇA

öz

Yapay zekâ, hayatlarımızı değiştirmeye devam ediyor. Ancak toplum içinde işlevi artarken yapay zekânın belirsiz ve öngörülemez karakteri, her bilimsel gelişmeden farklı olarak hukuk için yeni bir mücadele alanı da yaratıyor. Yaptığımız değerlendirmede, yapay zekânın hukuki kişiliğinin ve statüsünün belirlenmesinde, tüzel kişilik ve elektronik kişilik kavramlarının geliştirilmesi üzerinde durulması gerektiğini düşünüyoruz. Öte yandan yapay zekâ türleri geliştikçe ve yapay zekâ kendi farkındalığına vardıkça daha karmaşık hukuki sorunlar oluşabilecektir. Makalenin üzerinde durduğu konulardan biri, her bilimsel gelişmede olduğu gibi yapay zekâ teknolojisi karşısında hukukun, zamanlama ve içerik konusunda içinde bulunduğu ikilemdir. Hukukun buradan çıkış bulabilmesi için bir yol haritası oluşturulması gereklidir. Diğer hukuk dalları gibi idare hukukunun da yapay zekâ gelişmelerinden soyutlanamayacağı çalışmamızda ortaya konulmaktadır. İdare hukuku hem görev alanı hem de kurum ve kavramları itibariyle yapay zekâdaki gelişmelerden etkilenecektir. $\mathrm{Bu}$ nedenle organik ve fonksiyonel anlamda idarenin yapay zekâ etkisi ile kendi içinde dönüştüreceği konuları hiç de az değildir. Yapay zekânın verdiği zararlar sebebiyle idarenin sorumluluğu alanında, kusursuz sorumluluk ilkesinin uyarlanması veya yeni bir ilke geliştirilmesini düşünmek gerekir. İdare hukukunun içtihadi karakteri sayesinde, yapay zekâ alanındaki gelişmelere yeterli ve zamanında cevaplar üretilmesi mümkündür. Ayrıca, idare hukuku ve yapay zekâ arasında kurulacak ilişki, idari usul yasasına olan ihtiyacı tekrar gündeme getirebilecektir.

Anahtar Kelimeler: Yapay Zekâ, Hukuki Kişilik, Hukuki Statü, İdare Hukuku, Dijital Dönüşüm.

\begin{abstract}
Artificial intelligence continues to change our lives. However, while artificial intelligence increases its function in society, the uncertain and unpredictable character of artificial intelligence also creates a new challenge for law, unlike every scientific development. In our assessment, we think that the concepts of electronic personality and legal personality should be emphasized in determining the legal personality and legal status of artificial intelligence. On the other hand, as the types of artificial intelligence develop and the artificial intelligence becomes aware of itself, more complex legal problems will come to the agenda. One of the issues the article focuses on is the dilemma of the law regarding timing and content against artificial intelligence technology, as in every scientific development. For the law to find its way out, a road map should be created. In our study, it is revealed that administrative law, like other branches of law, cannot be abstracted from artificial intelligence developments. Administrative law will be affected by
\end{abstract}


developments in artificial intelligence, with its mandate, institution, and concepts. For this reason, there are not a few issues that the organic and functional administration will transform within itself with the effect of artificial intelligence. In the field of responsibility of the administration due to the damages caused by artificial intelligence, it is necessary to consider the adaptation of the strict liability principle or the development of a new one. Thanks to the jurisprudence character of administrative law, it is possible to produce adequate and timely responses to developments in the field of artificial intelligence. In addition, the relationship to be established between administrative law and artificial intelligence may bring the need for administrative procedure act back into the agenda.

Keywords: Artificial Intelligence, Legal Personality, Legal Status, Administrative Law, Digital Transformation.

\section{“Intibak kabiliyeti olan, yani makina yapılırken düşünülmemiş olan problemleri de çözebilen bir makina yapılabilir mi? ve nasıl yapılabilir? ${ }^{1 "}$}

\section{GíRiş}

Yapay zekâ sistemleri ile algoritma teknolojisinin hızlı gelişimi ve pratik hayatta yer almaya başlaması, hukuk sistemlerini meşgul etmeye başlamıştır. Toplumun değişen ihtiyaçlarına kayıtsız kalamayacağı için hukukun, yapay zekâ ile etkileşimini ilerletmesi ve bu alanda yeni kavram ve ilkelere kapı açması söz konusu olacaktır. Çünkü yapay zekâ teknolojisinin eşsiz ve öngörülemez yapısı karşısında mevcut hukuk sistemlerinin bu alanda yetersiz kalacağı ortadadır. Üstelik tecrübe biriktirme, öğrenme ve otonom/özerk kararlar verme yeteneğine sahip bir yapay zekâ senaryosunda, hukukun uygulamaya koyacağı araçların şimdiden düşünülmeye başlandığı ve tartışıldığ1 görülmektedir. Zira fütüristik fikirler, sürekli bir şekilde gerçek hayata dahil olmaya devam etmektedir. Mary Shelley'nin Frankenstein kurgusunun, bugün vatandaşl1k statüsü dahi bulunan yapay zekâ robotu Sophia ile nasıl gündelik tartışmaların içerisinde yer aldığı ortadadır.

1 ARF, Cahit, "Makine Düşünebilir mi ve Nasıl Düşünebilir?", Atatürk Üniversitesi 1958-1959 Öğretim Yılı Halk Konferansları, Atatürk Üniversitesi - Üniversite Çalışmalarını Muhite Yayma ve Halk Eğitimi Yayınları Konferanslar Serisi No: 1, Erzurum, 1959, s. 99. 
Tarihteki her teknolojik ilerlemenin, faydaları ve zararlarıyla geldiğini ve yapay zekânın da bundan farklı olmadığının altı çizilmelidir.

Şimdilik dünya üzerinde yaşadığımız tecrübeler ve mahkemelere yansıyan vakalar üzerinden görüleceği gibi yapay zekânın, hukukun birçok alanını ilgilendiren boyutu vardır. Yaptığımız literatür taramasında yapay zekâ ve hukuk ilişkisinin özel hukuk açısından medeni hukuk, borçlar hukuku, ticaret hukuku, fikri mülkiyet hukuku alanında; kamu hukuku açısından ise ceza hukuku, anayasa hukuku ve vergi hukuku alanında ele alındığı görülmüştür. Bu tabloya idare hukukunun da eklenmesi gerekmektedir. Yapay zekânın hukuk sistemlerinde yer almaya başlaması ile bu alanın düzenlenmesi ve denetlenmesi açısından idare hukukunu ilgilendiren yeni bir çalışma alanı ortaya çıkacak, idare hukukunun konusu olan kurumlar, kavramlar ve ilkeler üzerinde yeniden düşünme ihtiyacı doğacaktır. Biz de çalışmamızda, bugünden geleceğe kesin bir yargıya ulaşmak mümkün olmadığından, yapay zekânın başlangıcı aşamasında olduğumuz bu dönemde, idare hukukunun da geleceğine yönelik bir öngörü oluşturmak istedik. Gerek ulusal gerekse uluslararası platformlarda yapay zekânın hukukuna ilişkin yapılan çalışmaları inceleyerek, yapay zekâ meselesinin idare hukukçularının radarından uzakta olmaması gerektiği sonucuna ulaştık. Yapay zekânın ne olduğu, hukukla ilişkisinin nasıl görüldüğü, hukuki kişiliğinin nasıl tartışıldığı, hukuki statüsünün nasıl ele alındığ1, dünyadaki hukuki gelişmelerin nasıl ilerlediği, dünyada hukukçuların konuya dair görüşlerinin nasıl oluştuğu, idare hukukunda yapay zekâdan kaynaklı olarak nelerin değişebileceği, yapay zekânın düzenlenmesi ve denetlenmesinde ülkemizdeki mevcut gelişmelerin neler olduğu, idari usul ve idari işlem konularına yapay zekânın nasıl yansıyacağı, idarenin sorumluluğu bakımından yapay zekânın nasıl bir etki yaratacağı sorularının yanıtları bu çalışma ile birlikte aranmıştır.

\section{I. İDARE HUKUKU ve YAPAY ZEKÂ KAVRAMI}

Yapay zekâ sadece teknik bilimlerin değil aynı zamanda sosyal bilimlerin de gündemini işgal eden bir fenomen haline gelmiştir. Siyaset bilimi, felsefe, sosyoloji gibi disiplinlerin yanında hukuk, belki isteyerek belki de sırtından itilerek kendi ilkeleri bağlamında bu fenomeni kavramsallaştırma çabası içinde olmuştur. Yapay zekâ 
teknolojisinin ilerlemesi ve pratiğe dökülmesiyle birlikte, idare hukukunun konuları yapay zekâ kavramıyla kesişmeye başlamıştır. İdare hukuku ile ilişkisini değerlendirmek için öncelik olarak yapay zekâ kavramını değerlendirmek gerekir. Yapay zekânın çıkış sebepleri, bu teknolojinin hukuk tarafından anlamlandırılmasını ve bu gelişime yetişmeye çalışan hukukçular tarafından sunulacak önerilerin altyapısını oluşturmasını sağlayacaktır. Ancak insan davranışını ve zekâsını taklit eden insan ürünü bir "yaratık" hayali yeni bir düşünce değildir. Yapay zekâ hayalinin fikirsel planı, devleti ve egemeni yapay olarak betimleyen Thomas Hobbes'a kadar götürülebilir. Hobbes, sosyal sözleşme ve ideal durum hakkında Leviathan adlı kitabının giriş bölümünde yapay bir hayvan yapmanın mümkün olabileceğini, yaşamı birtakım uzuvların deviniminden ibaret sayarak bunun içimizdeki asli bir aksamdan kaynaklandığını kabul ediyorsak, tüm otomatların (saatler gibi yaylar ve çarklar sayesinde kendi kendine hareket eden motorlar) yapay bir yaşamı olduğunu neden söylemeyelim sorusunu sorarken; kalp yerine yay, sinirler yerine sicimler, eklemler yerine çarkların bedene hareket verdiğini söylemiştir².

Bilimdeki her gelişmede olduğu gibi yapay zekâ teknolojisi de bir günde ortaya çıkmamıştır. Birinci Sanayi Devrimi ile 18. yüzyılda buhar ve basit üretim otomasyonu kullanılmış; İkinci Sanayi Devrimi ile 19. yüzyılda kimya ve ağır sanayiler geliştirilmiş; Üçüncü Sanayi Devrimi ile 20. yüzyılda internet oluşturulmuş ve bilgisayar teknolojisi geliştirilmiş; Dördüncü Sanayi Devrimi ile yapay zekâ, nesnelerin interneti (IoT), blok zincir uygulamalarının endüstride kullanım alanı yaygınlaşmıştır. Bilimsel gelişmelerle kendini yenileyen sanayi devrimlerinin, dünya üzerinde siyasal, sosyal, ekonomik ve hukuki etkilerinin zincirleme bir şekilde devam ettiği sabittir.

Fiziksel işleri yapabilen makineler olarak ifade edebileceğimiz robotlar da konunun diğer boyutudur. Yapay zekâ teknolojisi, üretim teknolojisi, mobil teknoloji, bilgi ve iletişim teknolojisi, robotik gibi pek çok alanı beslemektedir. Robotik, yapay zekâ

"Nature (the art whereby God hath made and governs the world) is by the art of man, as in many other things, so in this also imitated, that it can make an artificial animal. For seeing life is but a motion of limbs, the beginning whereof is in some principal part within, why may we not say that all automata (engines that move themselves by springs and wheels as doth a watch) have an artificial life?", HOBBES, Thomas, Leviathan ("Hobbes's Leviathan reprinted from the edition of 1651), Clarendon Press, Oxford, 1909, s. 7, http://files.libertyfund.org/files/869/0161 Bk.pdf (Erişim Tarihi: 21.05.2021). 
teknolojisinin yoğun olarak somutlaştığı bir alandır. Fiziksel ve zihinsel bağlamda özne nitelikleri gösteren ama biyolojik anlamda hayatta olmayan inşa edilmiş sistemlere robot ismi verilmektedir ${ }^{3}$. Aslında otomatlar ve insan benzeri makineler fikri milattan öncesine götürülebilir; Yunan matematikçi Archytas tarafından yapılan tahtadan uçabilen mekanik bir güvercin (M.Ö. 4.уy.); M.Ö. 250 yılında İskenderiyeli Ktesibios’un icadı olan clepsydra isimli su saatini (klesibos pompas1); Arap ve Müslüman mucit olan El Cezeri'nin çok sayıda tasarlayıp ürettiği otomatik makineler, humanoid (insana benzeyen) ve dünyada ilk örneği olan programlanabilir robotlar (1136-1206); Leonardo da Vinci'nin 1495 yılında tasarladığı humanoid mekanik şövalye gibi ${ }^{4}$. Robot kelimesi, Çekçe'de roboti, zorunlu iş gücü, ağır iş, kölelik ve angarya anlamlarına gelmektedir. İlk kez, Çek yazar Karel Čapek'in 1920’de Rossum'un R.U.R. (Rossumovi Univerzální Roboti”), Türkçe ismiyle Rossum'un Evrensel Robotları adlı oyununda robot kelimesi kullanılmıştır ${ }^{5}$. Düşünebilen robot fikri ise 1950'li yıllardan itibaren olgunlaşmaya başlamıştır. Yapay zekâya sahip robotun özgür bir iradesi olup olmayacağı konusundaki tartışmalar, bu alandaki gelişmelere göre daha elle tutulur bir hale gelmeye başlamıştır ${ }^{6}$.

Bilimsel yönüyle yapay zekâ, 1950’lerde Alan Turing ve John von Neumann gibi önemli bilim insanlarının çalışmalarıyla ortaya konmuştur. Elektronik bilgisayarı ortaya ilk koyan Alan Turing'in 1936 yılında yayınlamış olduğu “On Computable Numbers, with an Application to the Entscheidungsproblem" (Hesaplanabilir Sayılar Üzerine,

3 ERSOY, Çağlar, Robotlar, Yapay Zekâ ve Hukuk, On İki Levha Yayıncılık, İstanbul, 2019, s. 6.

4 GASPARETTO, Alessandro, "Robots in History: Legends and Prototypes from Ancient Times to the Industrial Revolution", Explorations in the History of Machines and Mechanisms, History of Mechanism and Machine Science, Ed. LÓPEZ-CAJÚN, Carlos/CECCARELLI, Marco, Volume: 32, 2016, s. 41 vd., https://doi.org/10.1007/978-3-319-31184-5 5 (Erişim Tarihi: 12.11.2020).

51921 'de sahnelenen oyunda, robotlar her şeyi hatırlar ve yeni hiçbir şey düşünmez. Domin'e (fabrika müdürü) göre, robotlar iyi üniversite profesörleri olurlar. Bir zaman, robotun teki çalışmayı bırakır ve dişlerini gıcırdatmaya başlar. İnsan yöneticiler böyle bir olayı bir ürün kusurunun kanıtı olarak görürler, ancak Helena (robotları özgürleştirmek isteyen) bunu, ortaya çıkan ruhun bir işareti olarak yorumlamayı tercih eder. NILSSON, Nils J., The Quest for Artificial Intelligence: A History of Ideas and Achievements, Cambridge, UK, Cambridge University Press, 2010, s. 23-24, https://ai.stanford.edu/ nilsson/QAI/qai.pdf (Erişim Tarihi: 12.11.2020).

6 Yapay zekânın felsefi ve bilimsel açıdan özet tarihi için bkz. BUCHANAN, Bruce G., "A (Very) Brief History of Artificial Intelligence", AI Magazine, Volume: 26, No. 4, 2005, s. 53-60, https://doi.org/10.1609/aimag.v26i4.1848 (Erişim Tarihi: 12.11.2020). 
Karar Problemi Üzerine Bir Uygulama ile) başlıklı makalesi ${ }^{7}$ yapay zekâ teknolojisi için bir mihenk taşıdır ${ }^{8}$. Matematik profesörü John McCarthy'in de aralarında olduğu 1955'te sunulan "Dartmouth Summer Research Project on Artificial Intelligence" (Dartmouth Yapay Zekâ Yaz Araştırma Projesi) çalışmasında ilk kez kullanılan yapay zekâ terimi, insanın zeki olarak nitelendirilmesine neden olan davranışların, bir makine tarafından yapılmasını sağlamak biçiminde ve bir sorun ("the artificial intelligence problem") olarak ele alınmıştır'. 1960'lar ve 1970'lerde bu alanda önemli girişimler olmuştur; doğal dil işleme, mobil robotik alan, makine öğrenim sistemi, bilgisayarlı görü, vs. 1980'lerde ise yapay zekâya ilgi azalmış olup alanda önemli bir pratik başarıya ulaşılamazken ("Yapay Zekâ Kışı" olarak da ifade edilmektedir); 1990'larda internetin de devreye girmesiyle yapay zekânın günlük yaşamlarımıza etkileri oluşmaya başlamıştır ${ }^{10}$.

İnsanların entelektüel süreçlerinin bütünü anlamındaki yapay zekânın, mantığ1 anlama, geçmiş deneyimlerden öğrenme ve anlamları belirleme yeteneğine sahip olduğu belirtilebilir. Yapay zekâ, insanlardaki doğal zekâya benzer olarak görülebilen, makinelerde yazılım programları tarafindan üretilmektedir. Öte yandan yapay zekâya dair genel-geçer bir tanım yoktur. Yapay zekâ teriminde, "yapay" kavramını anlamanın kolaylığı karşısında asıl zorluk “zekâ” kavramını anlamaktır. Zekâ kavramının belirsizliği yapay zekânın tanımı üzerinde bir birlik olmasını da güçleştirmektedir. İnsanlar zekâya sahip olan tek varlık olduğundan, zekâ tanımlarının insan özelliklerine bağlı olma eğiliminde olmasının şaşırtıcı olmadığı ifade edilmektedir ${ }^{11}$. Bir diğer çalışmada yapay

7 TURING, Alan M., "On Computable Numbers, with an Application to the Entscheidungsproblem", Proceedings of the London Mathematical Society, Series 2, Volume: 42, Issue: 1, 1937, s. 230265, https://www.cs.virginia.edu/ robins/Turing Paper 1936.pdf (Erişim Tarihi: 12.11.2020); TURİNG, Alan M., "Computing Machinery and Intelligence”, Mind, Volume: 59, No. 236, 1950, http://www.jstor.org/stable/2251299 (Erişim Tarihi: 12.11.2020).

8 Turing'in 1950 tarihli "Computing Machinery and Intelligence” (Bilgisayar Mekanizması ve Zekâ) isimli makalesi de yapay zekâ felsefesi için temel bir role sahiptir, TURING, 1950, s. 433-460.

9 MCCARTHY, John/MINSKY, Marvin L./ROCHESTER, Nathaniel/SHANNON, Claude E., A Proposal for Dartmouth Summer Research Project on Artificial Intelligence, 1955, s. 11, http://jmc.stanford.edu/articles/dartmouth/dartmouth.pdf (Erişim Tarihi: 12.11.2020).

10 NILSSON, 2010, s. $71 \mathrm{vd}$.

11 MCCARTHY, John, What is Artificial Intelligence?, 2007, s. 3, http://wwwformal.stanford.edu/jmc/whatisai.pdf (Erişim Tarihi: 12.11.2020). 
zekâ, bir insan tarafindan yapıldığında zekâ gerektirdiği söylenebilecek görevleri yerine getirme yeteneğine sahip makineler olarak tanımlanmıştır ${ }^{12}$.

Aslında yapay zekâya dair tek tanım yokluğunun bu alanın büyümesine, çiçek açmasına ve sürekli ivme kazanan bir hızda ilerlemesine yardımcı olduğu da ifade edilmiştir"13. Nitekim Avrupa Komisyonu'nun 19 Şubat 2020 tarihli ve "Yapay Zekâ Üzerine Beyaz Kitap - Mükemmellik ve Güvene Avrupa Yaklaşımı” isimli raporunda, herhangi bir yeni hukuk metninde yapay zekâ tanımının, gerekli hukuki kesinliği sağlayacak kadar açık olması gerektiğinin yanında, teknik ilerlemeye uyum sağlamak adına yeterince esnek olması gerektiğinin de altı çizilmiştir ${ }^{14}$. 21 Nisan 2021 tarihinde tanıtılan Avrupa Birliği' nin (“AB”), “Yapay Zekâya İlişkin Uyumlu Kurallar Koyulması ve Bazı Avrupa Birliği Düzenlemelerinin Değiştirilmesi” (Yapay Zekâ Kanunu) başlıklı taslak metninde ${ }^{15}$ ise yapay zekâ sistemi; metindeki ekte listelenen tekniklerden ve yaklaşımlardan biri veya daha fazlasıyla geliştirilen ve belirli bir insan tanımlı hedef kümesi için etkileşimde bulundukları ortamları etkileyen içerik, tahminler, öneriler ve kararlar gibi çıktılar üretebilen yazılım olarak tanımlanmıştır (m. 3/1).

Yakın geçmişle birlikte insanlığın ortaya koyduğu zekâya sahip bu yapay yaratım için daha yolun başında olduğumuzu belirtmek gerekir. Yapay zekâ bugün itibariyle beslendiği algoritma ile problem çözme işlevi ve diğer tüm işlevleriyle, okullarda, evlerde ve hastanelerde kısaca hayatımızın tam içinde şimdiden hızlı bir şekilde büyümektedir; akıllı arabalar, ev temizlik robotları, güvenlik sistemleri, e-ticaret ve e-reklam

12 SCHERER, Matthew U., "Regulating Artificial Intelligence Systems: Risks, Challenges, Competencies, and Strategies", Harvard Journal of Law \& Technology, Volume: 29, No. 2, 2015, s. 362 http://jolt.law.harvard.edu/articles/pdf/v29/29HarvJLTech353.pdf (Erişim Tarihi: 12.11.2020).

13 STONE, Peter/BROOKS, Rodney/BRYNJOLFSSON, Erik vd., "Artificial Intelligence and Life in 2030", One Hundred Year Study on Artificial Intelligence: Report of the 2015-2016 Study Panel, $\begin{array}{lllll}\text { Stanford } \quad \text { University, } & \text { Stanford, } & \text { CA, 2016, } & \text { S. } & 12 \text {, }\end{array}$ https://ai100.stanford.edu/sites/g/files/sbiybj9861/f/ai 100 report 0831fnl.pdf (Erişim Tarihi: 12.11.2020).

14 Raporda yapay zekâyı oluşturan "veri” ve "algoritma" unsurlarının açığa kavuşturulmasına da dikkat çekilmiştir. White Paper, On Artificial Intelligence - A European Approach to Excellence and Trust, $\quad$ https://ec.europa.eu/info/sites/info/files/commission-white-paper-artificial-intelligencefeb2020 en.pdf (Erişim Tarihi: 12.11.2020).

15 Proposal for a Regulation Laying Down Harmonised Rules on Artificial Intelligence (Artificial Intelligence Act), https://digital-strategy.ec.europa.eu/en/library/proposal-regulation-laying-downharmonised-rules-artificial-intelligence-artificial-intelligence (Erişim Tarihi: 15.11.2021). 
uygulamaları, finans sektöründe sanal asistanlar, sağlık sisteminde akıllı teşhis ve tedavi planları, vs ${ }^{16}$. Örneğin Çin tarafından Internet Mahkemesi bünyesinde “AI Judge” (Yapay Zekâ Hakim) adı verilen yapay zekâ teknolojisini kullanan bir yazılım modülü geliştirildiği, modülün sesi, yüz ifadeleri ve gerçek kişiyi temel alan eylemleri olan bir kadın imajına sahip olduğu, kullanıcılarla iletişime geçerek gerçek zamanlı olarak dava rehberliği sağladığı 2019 yılında duyurulmuştur ${ }^{17}$.

İnsan duygularını ve düşüncelerini anlayıp iletişim kuran, kendisinin farkında olan ve bir "bilinç" geliştiren yapay zekâ türü ise şu aşamada filmlerde ve kitaplarda yer almaktadır. Ancak, bu tür de hızla ilerlemektedir ve yapay zekâ türü olarak ilgi çekmeye devam etmektedir. Google'ın DeepMind şirketinin projesi olan AlphaGo isimli program ile oluşturulan AlphaGo Zero'nun kendilik bilinci testini geçmesi, yapay zekânın gelecekteki yerinin ne şekilde olacağı konusunda sesleri yükseltmiştir. Go oyununu oynayan AlphaGo programı, her hareketten öğrenen yapay sinir ağlarına dayanmakta olup, insan oyunculuğu uzmanlarının yüklediği yapay sinir ağları ile pekiştirmeli öğrenme ile oyunu geliştirmiştir. Mevcut hukuki düzenlemelerin konusu olan yapay zekâ ile yapay sinir ağı tabanlı yapay zekâ sistemi arasında temel farklar olduğu, Alpha Go gibi, kendi kendine öğrenen yapay zekâ sistemi için ayrı bir hukuki çerçeve oluşturma ihtiyacını artıracağı ifade edilmektedir ${ }^{18}$. Üstelik sonraki model olan Alpha Go Zero, öncekinden farklı olarak, tamamen kendi kendisiyle go oynayarak sıfırdan öğrenmeye dayalı bir sistem algoritmasına sahiptir, ki kısa zamanda oyuna hükmetmiştir ${ }^{19}$.

16 Örneğin, robotik cerrahi alanında dünyadaki ilk sistem “ $D a$ Vinci”, ülkemiz de dahil olmak üzere birçok ülkede cerrahi ameliyatlar gerçekleştirmekte, bu minyatür aletler sayesinde daha hassas hareketlerle işlem yapıldığı ifade edilmektedir. Karar verme mekanizmasına sahip olmasa da yakın gelecekte bu ihtimalin gerçekleşmesi de muhtemeldir. İstanbul Üniversitesi, "Robotik Cerrahi Cihazı 'Da Vinci' Yara İzi Bırakmıyor", https://www.istanbul.edu.tr/tr/haber/robotik-cerrahi-cihazi-da-vinci-yara-izibirakmiyor-4D0077006C0069007A005600360071007000570049003100 (Erişim Tarihi: 12.11.2020).

17 "Beijing Internet Court Launches AI Judge", http://www.xinhuanet.com/english/2019-

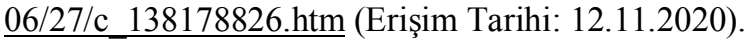

18 PALIWALA, Abdul, "Rediscovering Artificial Intelligence and Law: An Inadequate Jurisprudence?", International Review of Law, Computers \& Technology, Volume: 30, Issue: 3, 2016, s. 112, http://dx.doi.org/10.1080/13600869.2016.1229651 (Erişim Tarihi: 12.11.2020)

19 SILVER, David/SCHRITTWIESER, Julian/SIMONYAN, Karen vd., "Mastering the Game of Go without Human Knowledge", Nature, Volume: 550, Issue: 7676, 2017, s. 354-359, https://doi.org/10.1038/nature24270 (Erişim Tarihi: 12.11.2020). 
Dolayısıyla Turing'in "Makineler düşünebilir mi?" sorusunu daha sıklıkla sormaya başladığımız bir çağın içinde bulunmaktayız.

Yukarıda kavramsal olarak ele aldığımız ve gelişimini incelediğimiz yapay zekâ, diğer hukuk dallarında olduğu gibi idare hukukunun da konusunu oluşturmaya başlamıştır. Kamu hizmetlerinin yürütülmesinde yapay zekâ teknolojisinden faydalanılması yanında, yapay zekâya dair konuların düzenlenmesi ve bu alandaki aktörlerin denetlenmesi yani idarenin kolluk faaliyeti önem kazanmaktadır. Böylece yapay zekâ, son yıllarda idare hukukunun değișen ve gelişen faaliyet alanına yeni aç1lımlar getirecektir. Bu alanda, idarenin özendirme ve destekleme faaliyeti de görünür hale gelebilecektir. Aşağıda değerlendirdiğimiz üzere idarenin organik açıdan genişlemesi ile yapay zekâ dahil olmak üzere dijital dönüşümde ihtisaslaşan idari birimler oluşturulmaya başlanmıştır. Söz konusu idarelerin görev ve yetki alanı incelendiğinde, yapay zekâya ilişkin projelerin ve altyapı girişimlerinin desteklenmesine, katkıda bulunulmasına ve öncülük edilmesine yönelik amaçlar göze çarpmaktadır. İdare hukuku ve yapay zekâ ve ilişkisinin bir diğer konusunu ise idarenin sorumluluğu oluşturmaktadır. Uyuşmazlıklar idari yargının önüne gelmeye başladığında, yapay zekânın kullanıldı̆̆ı eylem ve işlemlerle ilgili olarak idarenin sorumluluğu ilişsin ilkelerin gözden geçirilmesi ve geliştirilmesi muhtemeldir. Çalışmamızın ilerleyen başlıklarında, idare hukuku ve yapay zekâ ilişkisine dair çeşitli tespitler ve olasılıklar değerlendirilecektir.

\section{II. İDARE HUKUKUNUN YAPAY ZEKÂ İLE İLISŞKISISINDEKİ ÖNCELİKLİ HUKUKİ KONULAR}

Bugün için hukukçuların gündeminde olan iki temel konu, yapay zekânın hukuki statüsünün ve sorumluluk rejiminin belirlenmesidir. Söz konusu temel konular, yapay zekânın idare hukuku boyutunu da şekillendirecek öneme sahiptir.

\section{A. Yapay Zekânın Hukuki Statüsü: Hukuk İçin Bir Meydan Okuma}

Yapay zekâya ilişskin hukuki tartışmaların, yapay zekânın hukuki kişiliği ve hukuki statüsü üzerinden hareketle yürütüldüğü belirtilebilir. $\mathrm{Bu}$ başlıkta, farklı türler 
çerçevesinde yapay zekânın hukuki kişiliğine yönelik görüşlerin değerlendirilmesi, akabinde hukuki statüsüne ilişkin tespitlerin sunulması söz konusu olacaktır.

\section{Yapay Zekânın Hukuki Statüsünün Belirlenmesindeki Dinamikler: Hukuki Kişilik Tartışmaları ve Gelişen Yapay Zekâ Türleri}

Yapay zekânın hukuki statüsünün değerlendirilebilmesi için öncelik yapay zekâya hukuki kişilik tanınıp tanınmayacağı hususunun ele alınması gereklidir. Kişi (personne, persona), rasyonel bir insan olarak kendi tutum ve davranışlarını yönetme yeteneğine sahip bireydir ve bilinç ve özgür iradenin varlığını ifade eder. Peki yapay zekâ bu gerekliliklerden herhangi birini karşılamakta mıdır? Genel olarak hukukta kişi, haklara ve borçlara sahip olabilen varlıklar olarak ele alınabilir. Kişilik ise hukuki işlem yapabilme, hak ve borç altına girebilme gibi sonuçları ve hukukun koruduğu hukuki, maddi ve manevi nitelikteki değerleri kapsayan bir kavramdır ${ }^{20}$. Günümüzde hukuk, gerçek kişiler dışında soyut/kurgusal kişileri tanımakta ve onlara da kişilik bahşetmektedir. Çeşitli ihtiyaçlar, elle dokunulur ve gözle görülür olmayan varlıklara da hukuki bir kişilik tanınması sonucunu doğurmuştur. Kaldı ki, tarihe baktığımızda insan dediğimiz hak öznesinin biricik temelinin bile "kişı" olarak sayılması belirli bir sürecin sonu olup, dünya üzerindeki her insanın kişiliğinin hukukça tanınması çok da uzak bir geçmişe denk gelmemektedir. Ahlaki duygusu çok az olan veya hiç olmayan ve yasal sorumlulukları az olan bebeklere de modern hukuk tarafından kişilik tanınması örneği verilmektedir ${ }^{21}$. Öte yandan sahiplerinin ne yaptığını "bilen” ve yapmalarını istemeyen

20 DURAL, Mustafa/ÖĞÜZ, Tufan, Türk Özel Hukuku, Kişiler Hukuku, Cilt II, 18. Basım, Filiz Kitabevi, İstanbul, 2017, s. 6 vd.; İMRE, Zahit, Medeni Hukuka Giriş, 3. Basım, Fakülteler Matbaası, İstanbul, 1980, s. 328; ÖZSUNAY, Ergun, Medeni Hukukumuzda Tüzel Kişiler: Tüzel Kişilerin Genel Teorisi, Dernekler, Vakıflar (Tüzel Kişiler), 5. Basım, Sulhi Garan Matbaası, İstanbul, 1982, s. 5-6 vd.; TEKINAY, Selâhattin Sulhi, Medenî Hukukun Genel Esasları ve Gerçek Kişiler Hukuku, 6. Basım, Filiz Kitabevi, İstanbul, 1992, s. 248; ÖZAY, İl Han, Günışığında Yönetim, Filiz Kitabevi, İstanbul, 2004, s. 119; GÖZLER, Kemal, İdare Hukuku, Cilt I, 3. Basım, Ekin Yayınevi, Bursa, 2019, s. 189.

21 CHOPRA, Samir/WHITE, Laurance, "Artificial Agents: Personhood in Law and Philosophy", Proceedings of the 16th Eureopean Conference on Artificial Intelligence, ECAI'2004, 2004, s.y., http://www.sci.brooklyn.cuny.edu/ schopra/agentlawsub.pdf (Erişim Tarihi: 12.11.2020). 
köpekler gibi zeki hayvanların itaatsizlik nedeniyle cezalandırıldığını, ancak bu nedenle de onlara tüzel kişilik kazanmaları gerektiğinin düşünülmeyeceği de eklenmektedir ${ }^{22}$.

Yapay zekânın hukuki anlamda bir kişi olamayacağını ifade edenler, yapay zekâya ilişkin konuların mevcut kurallar çerçevesinde ele alınabileceğini, bir nesne (eşya) olarak kabul edilmesinin yeterli olacağı yönünde argümanlar sunmaktadır ${ }^{23}$. Bu görüştekiler, özerkleşmeden/otonomlaşmadan kaynaklanan sorunların ilgili alana bağlı olarak çözülebileceğini, öngörülen sigorta ve sorumluluk sisteminin yeterli olacağını savunmaktadır ${ }^{24}$. Kanaatimizce, yapay zekâyla bağlantılı konular, hukukun mevcut kurallarıyla cevap veremeyeceği kadar geniş kapsamlıdır. Yapay zekânın henüz başlangıç aşamasında ortaya çıkan hukuki tartışmalar, bu alandaki sorunların çözümünde farklı bir yaklaşım oluşturulmasını gerekli kılmaktadır. Şu an için mantıklı görülmese dahi yapay zekânın ayrı bir kişiliğinin olması, ekonomik ve cezai bakımdan pek çok hukuki sürecin yürütülmesinde kolaylıklar sağlayacaktır. Dolayısıyla, yapay zekâya hukuki kişilik atfedilmesinin gerektiği düşüncesindeyiz. Konuya sözleşme akdedilmesi yönünden bakıldığında, giderek otonomlaşan ve sahibinin özel direktifi hatta bazen bilgisi dahi olmadan sözleşmeler akdeden yapay zekâların, kişisel bilgisayarlar gibi sahibinin eşyası olarak nitelendirilmesinin, yapay zekâların işlev ve fonksiyonlarıyla uyuşmayacağı gibi sözleşmelerin geçerliliğini tartış1lır hale getireceği belirtilmişti² ${ }^{25}$. Bir çalışmada bilimin, yapay zekâların davranışlarını üreten temel süreçlerin insan zihninin süreçlerine nispeten benzer olduğunu onayladığg takdirde, yapay zekâları kişi olarak ele almanın kolaylaşacağı ifade edilmektedir ${ }^{26}$. Başka bir çalışmada, hukuk sistemleri tarafından düzenlenen nesnelerin ya "ilk varoluş" (canlı/biyolojik) ya da "ikinci varoluş" (cansız/biyolojik

22 CHOPRA/WHITE, 2004, s.y.

23 PÉRENNOU, Thommas, "State of the Art on Legal Issues", Ethicaa Project, Ethics and Autonomus Agents, Ağustos 2014, s. 10-11, https://ethicaa.greyc.fr/media/files/ethicaa.delivrable.1.pdf (Erişim Tarihi: 12.11.2020).

24 PÉRENNOU, 2014, s. 10.

25 AKDAĞ, Şükrü Yakup, "Yapay Zekanın Sorumluluğu Üzerine Düşünceler", Sorumluluk Hukuku Seminerler 2018, Ed. BAYSAL, Başak, On İki Levha Yayıncılık, İstanbul, 2019, s. 12.

26 SOLUM, Lawrence B., "Legal Personhood for Artificial Intelligences", North Carolina Law Review, $\begin{array}{llllll}\text { Volume: 70, } & \text { No. } & 4, & 1992, & \text { s. } & 1287,\end{array}$ https://scholarship.law.unc.edu/cgi/viewcontent.cgi?article=3447\&context $=$ nclr $\quad$ (Erişim Tarihi: 12.11.2020). 
olmayan) olarak anıldığı belirtilerek, otonom zekâya sahip yeni nesil robotların içinse “üçüncü varoluş” kategorisinin oluşturulması savunulmuştur ${ }^{27}$.

Nitekim öğretide Duran, bilinç ve iradeden yoksun nesneler olarak nitelendirdiği tüzel kişilerin gerçekliğinin ya da gerçek dişılığının uydurma ve boş bir sorun olduğunu, çünkü hukukta insanların veya bireylerin "gerçek" denilen "kişiliğiı"nin de sanıldığı gibi, doğal ve zorunlu bir şey olmadığını, tarihi ve toplumsal evrimin çağımızdaki bir ürünü ve sonucu olduğunu ifade etmiştir ${ }^{28}$. Gerçekten de toplumsal yaşayışın ihtiyaçlarında doğan kişilik kavramı her hukuki kavram gibi durağan olmayıp, bu ihtiyaçların değişimi ile şekillenen bir içeriğge sahiptir. Örneğin, Yeni Zelanda 2017 yılında Whanganui kabilesi tarafından kutsal kabul edilen Whanganui nehrini hukuki kişi olarak kabul etmiştir ${ }^{29}$. Ekvador Anayasası, bir anayasa değişikliğiyle Pacha Mama yani Doğa Ana’yı hak sahibi varlık olarak tanımıştı1 ${ }^{30}$. Hindistan'da bulunan Yamuna ve Ganj nehirleri Uttarakhand Yüksek Mahkemesi'nin kararıyla kişi olarak tanınmış ${ }^{31}$; Buenos Aires Mahkemesi ise orangutan Sandra'yı insan olmayan kişi olarak tanıyarak zihinsel ve fiziksel durumuna uygun bir yaşam alanına nakline karar vermiştir ${ }^{32}$. Suudi Arabistan, 2017 yılında yapay zekâlı robota (Sophia) tam vatandaşlık veren ilk ülke olmuştur ${ }^{33}$.

27 WENG, Yueh-Hsuan/CHEN, Chien-Hsun/SUN, Chuen-Tsai, "The Legal Crisis of Next Generation Robots: On Safety Intelligence", ICAIL '07: Proceedings of the 11th International Conference on Artificial Intelligence and Law, 2007, s. 206, https://doi.org/10.1145/1276318.1276358 (Erişim Tarihi: 12.11.2020).

28 DURAN, Lütfi, İdare Hukuku Ders Notları, Fakülteler Matbaası, İstanbul, 1982, s. 62.

29 Te Awa Tupua (Whanganui River Claims Settlement) Act 2017, Public Act 2017, No. 7, 20.03.2017, http://www.legislation.govt.nz/act/public/2017/0007/latest/whole.html (Erişim Tarihi: 12.11.2020).

30 Ekvator Cumhuriyeti Anayasası 7. Bölüm “Doğanın Hakları” üzerine olup madde 71'e göre Pacha Mama (Doğa Ana), varlığını, yaşam döngüsünü, yapısını, işlevini ve evrimsel süreçlerini sürdürme ve yenileme hakkına sahiptir, Constitución Del Ecuador, https://www.ilo.org/dyn/natlex/docs/SERIAL/82263/89945/F253880992/Constitucion\%20de\%20Ecu ador\%202008.pdf (Erişim Tarihi: 12.11.2020).

31 High Court of Uttarakhand, Salim v. State of Uttarakhand, Writ Petition (PIL) No.126 of 2014 , 20.03.2017, https:/www.nonhumanrights.org/content/uploads/WPPIL-126-14.pdf (Erişim Tarihi: 12.11.2020).

32 "Asociacion de Funcionarios y Abogados por los Derechos de los Animales y Otros Contra Gcba Sobre Amparo, Expte. A2174-2015/0, 21.10.2015, https://ijudicial.gob.ar/wpcontent/uploads/2015/10/Sentencia-Orangutana.pdf (Erişim Tarihi: 12.11.2020).

33 "Meet the First-Ever Robot Citizen - A Humanoid Named Sophia that Once Said it Would 'Destroy Humans' ", Business Insider, 27.10.2017, https://www.businessinsider.com/meet-the-first-robotcitizen-sophia-animatronic-humanoid-2017-10? $\mathrm{r}=\mathrm{UK}$ (Erişim Tarihi: 12.11.2020). 
Hukuki statünün belirlenmesini gerektiren bir diğer dinamik ise gelişen yapay zekâ türleridir. Bir hukuki kişi gibi hak sahibi olabilecek ve sorumluluk alabilecek yapay zekâ türlerinin oluşacağ1, teknolojik ilerlemelerin ortaya koyduğu bir husustur. Bu durumda, tüzel kişilik gibi kurgusal varlıklara hukuki anlamda haklar ve sorumluluklar verilebilirken, yapay zekâlar bu kurgusallığın dışında bırakılabilir mi? Bu sorunun cevabını aramadan önce yapay zekânın kendi içinde farklı sınıflandırmalara tabi olduğuna dikkat edilmelidir. O nedenle net ve üzerinden uzlaşılmış bir cevabı olmayan zor sorularla hukukçuların teşriki mesaisinin kolay olmadığı ve farklı fikirlerin çarpıştığ açıktır. Dolayısıyla yapay zekâların türleri arasındaki farklılıkların da farklı hukuk kurallarına bağlanacağı söylenebilir. Yine, "Yapay zekâların temel hakları var mıdır?" sorusu da bu durumla bağlantılıdır. Özellikle algıları kendi programlanmaları ile sınırlı olmayan ve kendi öz farkındalığına sahip bir yapay zekânın duygu ve algılarının yapay olmadığı belirtildiğinden hak öznesi konumunda olup olmayacağı tartışmaları doğmaktadır. Kendi öz farkındalığına sahip olan yapay zekâların malvarlığına sahip olabilecekleri öne de sürülebilmektedir ${ }^{34}$. Bu nedenle yapay zekânın farklı kategorilerine göre farklı hukuki sonuçlara gidilebilir. Örneğin yapay zekânın dört farklı türünün olduğu tespiti üzerinden hareketle, yapay zekâ türleri şu başlıklarla sınıflandırılmaktadır: ${ }^{35}$ "reaktif makineler" (reactive machines), "sinırlı bellek" (limited memory), "zihin teorisi" (theory of mind) ve "öz farkındalık" (self-awareness).

Reaktif makineler, hafızası olmayan ve mevcut kararları etkilemek için geçmiş deneyimi kullanma yeteneğine sahip olmayan, aynı durumla her karşılaştıklarında aynı şekilde davranan sistemlerden oluşur. Bu türün klasik örneği olarak, dünya satranç şampiyonu Garry Kasparov’un yenildiği 1997'de IBM’nin “Deep Blue” isimli satranç programı olarak tasarlanan yapay zekâ verilebilir. ${ }^{36}$ Sınırlı (kısıtlı) hafızaya sahip

34 ALEXANDRE, Filipe Maia, The Legal Status of Artificially Intelligent Robots: Personhood, Taxation and Control, 2017, s. 23, http://dx.doi.org/10.2139/ssrn.2985466 (Erişim Tarihi: 12.11.2020).

35 HINTZE, Arend, "Understanding The Four Types Of AI, From Reactive Robots To Self-Aware Beings", The Conversation, 14.11.2016, https://theconversation.com/understanding-the-four-typesof-ai-from-reactive-robots-to-self- aware-beings-67616 (Erişim Tarihi: 12.11.2020).

361996 yılında yapılan ilk maçta Kasparov, Deep Blue’yu yenmiş iken, sonraki yılda geliştirilen Deeper Blue programına yenilmiştir. Yine, 2011 yılında IBM'in "Watson” adlı bilgisayarının 2011 yılında bir bilgi yarışmasında, en başarılı yarışmacıyı yenmiştir. Trips Reddy, "Why it matters that AI is better 
makineler, belirli anahtar nesneleri belirleyerek ve zaman içinde bunları izleyerek geçmişe bakma yeteneğine sahip makinelerdir ${ }^{37}$. Örnek olarak araç teknolojisinde sürücüye uyarılar yapan akıllı sistemler ve dijital asistanlar gösterilebilir. Zihin teorisi kategorisindeki makineler, davranışlarını başkalarının duygularına, beklentilerine, motivasyonlarına ve niyetlerine göre ayarlayabilirler ${ }^{38}$. İnsanlarla iletişim kurabilen bu türün gelişimi halen tamamlanmamış olup, tıp alanında kullanılmaya başlandığı görülmektedir. Öz farkındalığı olan yapay zekâlar ise bilinçli, duyarlı ve başkalarının duygularını anlayabilir, aynı zamanda ne istediklerini ve neden istediklerini de anlayabilirler ${ }^{39}$. Bu tür ise şimdilik olmayan ancak gelecekte olması muhtemel bir yapay zekâ türü olarak değerlendirilmektedir ${ }^{40}$. Kendisine hukuki kişilik atfedilen yapay zekânın statüsünün belirlenmesi arayışı, türler arasındaki farklılığın da bir getirdiği bir sonuçtur.

Nihayetinde, hak sahibi olabilen ve borç altına girebilen bir yapay zekânın varlığı kaçınılmaz olarak bir gök taşı gibi dünyaya yaklaşmaktadır. Yapay zekâların içinde bulundukları koşulların değişmesi ile ahlaki seçim ve hukuki seçeneklere karar verebilmesi durumu çok uzak değildir. Bu doğrultuda kesin bir yargıya varmak da mümkün değildir. Türk Medeni Kanunu'na göre tüzel kişiler, cins, yaş, hısımlık gibi yaradılış gereği insana özgü niteliklere bağlı olanlar dışındaki bütün haklara ve borçlara ehildirler. Yapay zekâlar da "şimdilik” insana özgü nitelikler taşımamaktadır. İnsana özgü nitelik taşımamak hukuk tarafından yapay varlıklara kişilik tanınmasına engel olmamıştır. İlerleyen zaman doğrultusunda ve bilimsel gelişmelerin etkisiyle, yapay

than humans at games like Jeopardy", 27.06.2017, https://www.ibm.com/blogs/watson/2017/06/whyit-matters-that-ai-is-better-than-humans-at-their-own-games/ (Erişim Tarihi: 12.11.2020).

37 Örnek olarak, Apple cihazındaki Siri uygulaması ve insansız arabalar olarak verilebilir.

38 Örnek olarak, bilim kurgu konulu eserlerindeki karakterler verilebilir; Star Wars filmindeki C-3PO ve R2-D2; I, Robot filmindeki Sonny gibi.

39 Ex Machina filmindeki Eva gibi.

40 Akıllı makineler hakkında insanlığa yaptığı uyarı ile ilgili gelen soruya Hawking yapay zekâ ile ilgili olarak insan seviyesinde bir yapay zekâ ve ötesini inşa etmenin ne kadar süreceği konusunda bir fikir birliği olmadığını, bu yüzden yapay zekânın yaşamımız boyunca olacağını veya yaşamınız boyunca olmayacağını bildiğini iddia eden kimseye güvenilmemesini ifade etmiştir. HAWKING, Stephen, "Science AMA Series: Stephen Hawking AMA Answers", 2015, https://www.reddit.com/r/science/comments/3nyn5i/science ama series stephen hawking ama ans wers (Erişim Tarihi: 12.11.2020). 
zekânın hukuki rejiminin oluşturulması için hukukta kişilik kavramına yeni açılımlar getirilmesinin kaçınılmaz olduğunu düşünüyoruz.

\section{Yapay Zekânın Hukuki Statüsünün Değerlendirilmesi}

Öğretide, hukuki statüsü ile ilgili olarak yapay zekânın; eşya, köle, tüzel kişi veya elektronik kişi olduğu yönünde farklı görüşler bulunmaktadır ${ }^{41}$. Bir diğeri de yapay zekâların "yapay insan” olarak sınıflandırılması önerisidir"42. Görüşlerin ayrıntılarına girmemekle birlikte, burada hukuki açıdan yeni olanın elektronik kişilik statüsü olduğu belirtilebilir ${ }^{43}$. Avrupa Parlamentosu Hukuk İşleri Komisyonu tarafından 16 Şubat 2017 tarihinde kararlaştırılan "Robotikler Hakkında Medeni Hukuk Kuralları Tavsiye Raporu” başlıklı raporda ${ }^{44}$ elektronik kişi yaklaşımı ortaya atılmıştır. Raporun "Genel ilkeler" başlıklı bölümünde (yapay zekâya sahip) robotların otonomluğu (özerkliği) “dış kontrol veya etkiden bă̆ımsız olarak karar alma ve dış dünyaya uygulama yeteneğ $i$ " olarak tanımlanmıştır ${ }^{45}$. Robotikler Hakkında Medeni Hukuk Kuralları Tavsiye Raporunda;

41 KILIÇARSLAN, Seda Kara, "Yapay Zekanın Hukuki Statüsü ve Hukuki Kişiliği Üzerine Tartışmalar", Yıldırım Beyazıt Hukuk Dergisi, Sayı: 2, Yı1: 4, 2019, s. 377 vd.

42 euRobotics, The European Robotics Coordination Action, Suggestion for a Green Paper on Legal Issues in Robotics, 2012, s. 62, https://www.unipv-lawtech.eu/files/euRobotics-legal-issues-inrobotics-DRAFT 6j6ryjyp.pdf (Erişim Tarihi: 12.11.2020). Burada, ahlaki otorite, sosyal bilinç, muhakeme akıl sağlığı, eylemlerin öngörülebilir sonuçları gibi temel kriterlerin nasıl oluşturulacağı hususunun ortaya konulması lazımdır. Bu nedenle bu fikrin önünde çözülmesi gereken birçok belirsizlik vardir.

43 "Elektronik kişsi" terimi, ilk olarak "Life" dergisinin 1967 yılında yayımlanan bir yazıda kullanılmışıtır, ROSEN, Charles/NILSSON, Nils/RAPHAEL, Bertram, "Shakey", Life, 1967, http://cyberneticzoo.com/cyberneticanimals/1967-shakey-charles-rosen-nils-nilsson-bertram-raphaelet-al-american/ (Erișim Tarihi: 12.11.2020).

44 Report with Recommendations to The Commission on Civil Law Rules on Robotics, 2015/2103 (INL), https://www.europarl.europa.eu/doceo/document/A-8-2017-0005_EN.html?redirect (Erişim Tarihi: 12.11.2020).

45 Komisyon, genel bir tanım getirmemekle birlikte çeşitli özellikleri sıralayarak akıllı robotu ele almıştır (m.1). Akıllı bir robotun aşağıdaki özelliklerini dikkate alarak siber fiziksel sistemler, otonom sistemler, akıllı otonom robotlar ve bunların alt kategorileri için ortak bir tanım getirme çabasında olmuştur;

- Sensörler aracıllı̆ıyla ve/veya çevresi ile veri alışverişi yaparak (ara bağlantı) özerklik elde etmesi ve bu verilerin değiş-tokuş etmesi ve analiz yapması;

- Deneyim ve etkileşim yoluyla kendi kendine öğrenmesi (isteğe bağl1 kriter);

- En azından küçük bir fiziksel desteği bulunması;

- Davranış ve eylemlerini çevreye uyarlaması; 
uzun vadede robotlar için belirli bir yasal statünün oluşturulması; böylece en azından karmaşık otonom robotların elektronik kişi (electronic persons) statüsünde kurularak verdikleri zarardan sorumlu olmalarının sağlanması; robotların otonom kararlar verdiği veya üçüncü şahıslarla bağımsız olarak etkileşime girdiği durumlarda elektronik kişiliğin (electronic personality) uygulanması tavsiye edilmiştir (m.59/f).

Yapay zekânın hukuki statüsünün, tüzel kişilik etrafında şekillendirilebilmesi bir seçenek olarak ele alınabilir. Bu doğrultuda sınırlı belleğe sahip makinelerin, bir zihin teorisine sahip makinelerin ve öz farkındalığa sahip makinelerin, sahiplerinden ve kullanıcılarından ayrı tüzel kişiler olarak görülmesi gerektiği ifade edilmiştir ${ }^{46}$. Tüzel kişilerin sahip olması gereken özellikler hukuk tarafından belirlenmiştir. Hukukumuzda tüzel kişiler "numerus clausus" ilkesine uygun olarak düzenlenmiştir. Tüzel kişilerin kendiliğinden oluşması kabul edilmemiş, pozitif hukukta öngörülen kurallar çerçevesinde hukuki varlık kazanacakları kabul edilmiştir. Hukuk sisteminin bağımsız bir hukuk süjesi olarak tanıdığı tüzel kişiler, kendilerini oluşturan gerçek kişilerden ve üçüncü kişilerden bağımsız olarak hareket kabiliyetine sahiptirler. Bu doğrultuda yapay zekânın tüzel kişiler gibi; belirli bir kişiliğe ve menfaate sahip olabileceği, haklarının ve sorumluluklarının belirlenebileceği, bir sicile kaydedilerek mal varlığına sahip olabileceği gibi fikirler öğretide dile getirilmiştir ${ }^{47}$.

Eklemek gerekir ki, tüzel kişilik bugünkü hukuk anlamında yapay zekâ araçları için tam bir karşılığa sahip olmayacaktır. Çünkü tüzel kişilik ilke olarak hak ve görevlere sahip olma sorunudur. Güncel süreçte "zekâ" ve "irade” açısından donanımlı bir yapay zekâ ortaya çıkmadığından, tüzel kişilik meselesinin kurgusal planda kalması gerektiği ileri sürülebilir bir düşüncedir. Öğretide, tepkisel yapay zekâ ve otonom yapay zekâ şeklinde de ayrımın yapıldığı; öngörülebilir olmaları ve üreticisi, programcısı ya da kullanıcısı tarafından kendisine verilen komutları yerine getirerek onların iradelerini tam olarak yansıtmaları sebebiyle, ürün ya da araç olarak değerlendirilen tepkisel yapay

- Biyolojik anlamda bir yaşam olmaması.

46 ALEXANDRE, 2017, s. 31.

47 ALEXANDRE, 2017, s. 16 vd. 
zekâlara, ayrı bir hukuki statü tanınmasında hukuki yarar bulunmadığı da ifade edilmektedir ${ }^{48}$.

İnsan müdahalesine ihtiyaç duymaksızın ilerlemeye devam eden yapay zekâya bugün olmasa bile gelecekte, türleri içindeki farklılıklar da gözetilerek, tüzel kişilik ya da elektronik kişilik gibi bir hukuki statünün tanınması gerektiği düşüncesindeyiz. Dolayısıyla tüzel kişilik kavramının yeniden değerlendirilmesi ve koşullarının yapay zekânın türleri arasında farklılaştırılabilmesi ilk tercih olarak ele alınabilir. Yapay zekânın, dernekler, anonim şirketler gibi klasik anlamdaki tüzel kişilerin tabi olduğu hukuk kurallarıyla ele alınamayacağı ortadadır. Bu doğrultuda sınırlı bellek, zihin teorisi ve öz farkındalık türlerindeki yapay zekâlara tüzel kişilik tanınabilir ${ }^{49}$. Örneğin reaktif makine şeklindeki yapay zekâların ayrı bir hukuki kişiliğe sahip olamayacağı ve kişilik tartışmasının bu araçlar için yapılamayacağı belirtilebilir. Özellikle, otonom hareket eden ve eylemlerinin sonuçlarını bilen öz farkındalığa sahip bir yapay zekâ türünün, mülkiyet hakkı gibi bazı hakların sahibi konumuna getirilebilmesi mümkün olabilir ${ }^{50}$. İkinci bir tercih ise elektronik kişilik kavramı üzerinden gidilerek, yapay zekâya kendine özgü yeni bir kişilik statüsünün tasarlanmasıdır ${ }^{51}$. Sonuç olarak, yapay zekânın hukuki statüsünün belirlenmesinin, şu an için olmasa bile yakın gelecek için bir gereklilik olduğunu düşünüyoruz ${ }^{52}$.

48 AKDAĞ, 2019, s. 13.

49 Yapay zekâlı bilgisayarların, Amerikan Anayasası tarafından tüzel kişi olarak kabul edilme tartışması için bkz. WILLICK, Marshal S., "Artificial Intelligence: Some Legal Approaches and Implications,", Al Magazine, Volume: 4, No. 2, 1983, s. 7 vd., https://doi.org/10.1609/aimag.v4i2.392 (Erişim Tarihi: 12.11.2020).

50 Yapay zekâ sistemlerine, algoritmaya dayalı işlem doğasıyla tüzel kişilik verilebileceği, bu şekilde hukukun öznesi haline geldiklerinde benzerlerinden farklı olsa da çeşitli hak ve borçlara sahip olabilecekleri ifade edilmiştir, ČERKA, Paulius/GRIGIENĖ, Jurgita/SIRBIKYTĖ, Gintare, "Is it possible to grant legal personality to artificial intelligence software systems?", Computer Law \& Security Review, Volume: 33, Issue: 5, 2017, s. 12-13, https://doi.org/10.1016/j.clsr.2017.03.022 (Erişim Tarihi: 12.11.2020).

51 Yapay zekânın hukuki statüsü ile ilgili değerlendirmeler için bkz. BOZKURT YÜKSEL, Armağan Ebru/BAK, Başak, "Yapay Zeka", Futurist Hukuk, Aristo Yayınevi, İstanbul, 2018, s. 6 vd; BAYAMLIOĞLU Emre, "Akıllı Yazılımlar ve Hukuki Statüsü: Yapay Zeka ve Kișilik Üzerine Bir Deneme”, Uğur Alacakaptan'a Armağan, Cilt II, İstanbul Bilgi Üniversitesi Yayınları, İstanbul, 2008, s. 138 vd.; KILIÇARSLAN, 2019, s. 371 vd.

52 Bir robotun yer değiştirme, seçim yapma, çalışma, analiz etme, yorumlama, karar verme ve hissetme yetenekleri göz önüne alındığında yasal statüden yoksun bırakılamayacağı ifade edilmiştir, LEHMANWILZIG, Sam, "Frankenstein Unbound: Towards A Legal Definition Of Artificial Intelligence", 


\section{B. Yapay Zekâ ve Algoritma Teknolojisinin Şimdiden Düşündürdükleri ve Hukukun İçinde Bulunduğu İkilem}

Hukukun, teknolojinin temposuna ayak uydurmada güçlüklerle karşılaştığ1 belirtilmelidir. Bu durumu açıklamak için "Collingridge dilemma” (Collingridge ikilemi) kavramı kullanılabilir. 1980 tarihli "The Social Control of Technology" isimli kitabinda yeni teknolojileri yönetmenin zorlukları hakkında yazan David Collingridge'in adını taşıyan Collingridge ikilemi, meşhur cini şişeye geri koymanın zorluğuna atıfta bulunmaktadır. $\mathrm{Bu}$ teoriye göre değişim kolay olduğunda, ona olan ihtiyaç öngörülemeyecektir; ancak, değişim ihtiyacı ortaya çıktığında da değişim pahalı, zor ve zaman alıcı hale gelecektir ${ }^{53}$. İşte teknolojik değişimde, hukukun içinde bulunduğu ikilem de bu şekildedir. Henüz genç diyeceğimiz yapay zekâ teknolojisinin erken döneminde, bu teknolojinin kavranması sağlanamamışken hukuki düzenlemeler oluşturmak bu gelişimi sınırlayabileceği gibi; bu gelişimin etkilerini uzun süre bekledikten ve istenmeyen sonuçlar doğduktan sonra hukuki düzenlemeler oluşturmak ise zor, masraflı ve zaman alıcı bir sürece sebep olacaktır.

Collingridge ikilemi karşısında ise "Precautionary Principle" (İhtiyatlılık İlkesi) kavramından bahsedilmektedir ${ }^{54}$. Bilimsel belirsizliğe dayanan ve net bir tanımı olmayan bu ilkeye göre, riske katlanmaktansa faaliyete izin verilmemelidir ${ }^{55}$. Konumuz açısından yorumlayacak olursak geliştiricilerin bireylere, gruplara veya topluma bir bütün olarak zarar vermediğini göstermesine kadar yapay zekâ teknolojisinin benimsenmemesi gerekir. Ancak yapay zekâ teknolojisi gündelik yaşamımızda hem olumlu hem olumsuz sonuçlarıyla birlikte daha fazla benimsenir hale gelmektedir. Dolayısıyla modern dijital

Futures, Volume: 13, Issue: 6, 1981, s. 453, https://doi.org/10.1016/0016-3287(81)90100-2 (Erişim Tarihi: 12.11.2020).

53 HAGEMANN, Ryan/SKEES, Jennifer/THIERER, Adam D., "Soft Law for Hard Problems: The Governance of Emerging Technologies in an Uncertain Future", Colorado Technology Law Journal, Volume: 17, No. 1, 2018, s. 55 vd., https://ctlj.colorado.edu/wp-content/uploads/2019/03/3Thierer 3.18.19.pdf (Erişim Tarihi: 12.11.2020).

54 HAGEMANN/SKEES/THIERER, 2018, s. 56-57.

55 TURGUT, Nükhet, “İhtiyat İlkesi”, Ankara Üniversitesi Hukuk Fakültesi Dergisi, Cilt: 45, Sayı: 14, 1996, s. 67-102. 
dünya karşısında Precautionary Principle'ın yapay zekâ alanı için geri planda kaldı̆̆ 1 düşüncesindeyiz.

Öte yandan ekonomist Larry Downes'ın "The Laws of Disruption" adlı kitabinda atıfla; teknolojideki değişimin katlanarak arttığı, bunun karşısında sosyal, ekonomik ve hukuki sistemlerin değişiminin ise aşamalı olarak arttığı ifade edilmektedir ${ }^{56}$. Hukuk ve teknoloji ilişsisindeki bu durum karşısında "soft law" (esnek/yumuşak hukuk) kavramından yararlanılabilir.

Devletin standart hale getirdiği kural koyma prosedürlerini ve sonuçlarını içeren "hard law" (katı/sert hukuk) karşısında esnek hukuk, beklenti yaratan ve bağlayıcı olmayan ilkeler ve standartlar getirmektedir. Bir nev'i niyet içeren esnek hukuktaki ilke ve standartlar, uyuşmazlık çözümünde kolaylıkla uygulanma yeteneğine sahip değildir. $\mathrm{Bu}$ olumsuzluğuna rağmen, hızlı gelişen bir teknolojiyle uğraşıldığı da hesaba katılarak, esnek hukuk ile teknolojiden kaynaklı potansiyel zorluklarla daha az sorunlu çözümler üretilebilecektir. Zira teknolojik ilerlemenin ve yapay zekâdaki gelişmelerin yarattığı belirsizlik sebebiyle, bağlayıcı hukuk kurallarının işlerliği zaafa uğrayacaktır. Öğretide bu amaçla yumuşak hukuk enstrümanlarını kullanan bir Uluslararası "Yapay Zekâ Örgütü” (International Artificial Intelligence Organization/IAIO) oluşturulması da önerilmiştir ${ }^{57}$.

AB’nin, yapay zekânın da dahil olduğu dijital dönüşüme yönelik düzenlemelerinde esnek hukuk yaklaşımını tercih ettiği belirtilebilir. Örneğin Almanya, Fransa, Danimarka, İspanya gibi ülkelerin bulunduğu on dört AB üyesi devletler 2020'nin Ekim ayında yayımladıkları raporda; $\ddot{o z}$ düzenleme (self-regulation) ${ }^{58}$, uzmanlık ilkeleri, diğer gönüllü uygulamalar gibi yumuşak hukuk çözümlerinin yanı sıra, güvenlik standartlarının karşılanmasını sağlayan mevcut mevzuata ek olarak güçlü bir standardizasyon sürecine

56 HAGEMANN/SKEES/THIERER, 2018, s. 59, dp. 137.

57 ERDÉLYI, Olivia J./GOLDSMITH, Judy, "Regulating Artificial Intelligence Proposal for a Global Solution", AIES '18: Proceedings of the 2018 AAAI/ACM Conference on AI, Ethics, and Society, 2018, s. 95-101, https://dl.acm.org/doi/10.1145/3278721.3278731 (Erişim Tarihi: 12.11.2020).

58 Farklı tanımlar olmakla birlikte öz düzenleme (self-regulation), doğrudan devlet kontrolü yerine yasal kurallara uyumun otokontrol ile sağlanması olarak özetlenebilir. Ayrıntılı bilgi için bkz. PRICE, Monroe E./VERHULST, Stefaan G., Self-Regulation and the Internet, Kluwer Law International, Hollanda, 2005, s. 3 vd. 
yönelme önerisi getirmişlerdir ${ }^{59}$. Esnek hukuk mekanizmalarının çok paydaşlı süreçleri içermesi sebebiyle sert hukuku oluşturmanın önünü açacağ 1 belirtilmelidir. Esnek hukuk, kurumsal çerçevenin başlangıç noktasında, devletler ile ulusal ve uluslararası kurumlar arasındaki iş birliğine faydalı olabilir. Öte yandan, yapay zekâ alanında geleneksel hukuk normlarının oluşturulmasının arzu edildiği de unutulmamalıdır. Bu nedenle bu gönüllü standartların, yasal olarak bağlayıcı standartların benimsenmesine geçici bir alternatif olması gerektiğini akılda tutmak çok önemlidir.

Sonuç olarak, yapay zekâlara hukuki kişilik tanınması ve sorumluluk yüklenmesine dair yaklaşım, bugünün şartlarıyla "en uç nokta" olarak görülebilir. Ancak hukuk düzeninin; gemi şirket, ulus devlet, belediye gibi cansız varlıkları hak sahibi yani kişi olarak tanıması günümüzde tartışmasızdır. Bir şirketin "kendi” haklarına sahip olduğu ve pek çok anayasal/yasal amaç için "kişil” ve "vatandaş" olduğu fikrine oldukça alışık olmamızla birlikte, tüzel kişi kavramının ilk kez gündeme gelişinin hukukçular bakımından ne kadar sarsıcı olduğu hatırlarda tutulmalıdır ${ }^{60}$.

Hukukun, teknolojinin gerisinde kaldığ 1 yaygın bir gözlemdir. Bu gözlem doğru olmakla birlikte hukukun erkenci olması, Collingridge ikileminde ifade edildiği gibi istenmeyen çatışmalara da neden olabilir. Dolayısıyla yapay zekâ teknolojisi bakımından hukukun yaşadığı paradoksun devre dışı bırakılması için, kamu yararı kavramı üzerinden hareket etmesi gerektiği düşüncesindeyiz. Çünkü hukuk teknolojiyi değil, daha çok teknolojinin sosyal, politik ve ekonomik hayatın üzerindeki olumsuz etkilerini düzenlemelidir. $\mathrm{Bu}$ anlamda hukuk yapıcılarının yapay zekâ teknolojisini düzenleyen kurallar oluşturmada yaşadığ gerilimi; ex ante müdahaleye ağırlık veren bir yaklaşımda bulunulması, teknolojideki belirsizliğe istinaden esnek hukuk modelleriyle bir düzenleme alanının oluşturulabilmesi, konunun küresel boyutu sebebiyle ulusal ve uluslararası

59 Non-Paper - Innovative and Trustworthy AI: Two Sides of the Same Coin, Position paper on behalf of Denmark, Belgium, the Czech Republic, Finland, France, Estonia, Ireland, Latvia, Luxembourg, the Netherlands, Poland, Portugal, Spain and Sweden on Innovative and Trustworthy AI, 2020, https://em.dk/media/13914/non-paper-innovative-and-trustworthy-ai-two-side-of-the-same-coin.pdf (Erişim Tarihi: 12.11.2020).

60 STONE, Christopher D., "Should Trees Have Standing? Toward Legal Rights for Natural Objects", Southern California Law Review, Volume: 45, 1972, s. 452, https://iseethics.files.wordpress.com/2013/02/stone-christopher-d-should-trees-have-standing.pdf (Erişim Tarihi: 12.11.2020). 
organizasyonlarla işbirliği içinde olunması, kuralların oluşturulmasında demokratik süreçlerin takip edilmesi ve katılımcı bir usulle müzakere ortamının sağlanması, kamuya açık ve şeffaf bir hukuk politikasının tercih edilmesi gibi önerilerle aşabileceğini umuyoruz $^{61}$.

Yapay zekâyı daha iyi anlamak ve onu daha iyi kullanmak için ulusal ve uluslararası normlar, politikalar ve kurumlar geliştirilmeli, yasal bir envanter oluşturulmalıdır. Çünkü algoritma teknolojisinin gelişimi hukuk sistemlerine de meydan okumaya başlamıştır. Diğer taraftan, yeni teknolojilerin hukuki boyutunu ele alırken gerçeklikten kopuk ve abartılı senaryolardan kaçınmak ve hukukun evrensel ilkelerine bağlı kalmak gereği de ortadadır. Bugün için yapay zekâ, üzerinde tanım birliği bulunmayan, toplumsal hayatla doğrudan etkileşim halinde olan ve sonuçları açısından yüksek riskli belirsizlikleri olan bir teknolojidir. Peki bu kadar karmaşık bir sistem hukuk metinlerine nasıl dökülecektir? Çünkü yapay zekâ gerçek dünyada ilerledikçe, öngörülebilirlik açısından bu ilerlemeye zamanında ve doğru bir şekilde yetişmek önem kazanacaktır. Yapay zekâ sistemleri ve algoritma teknolojileri çok amaçlı hale geldikçe, önceden tahmin etme kabiliyeti de zorlaşacaktır. Yapay zekânın yıkıcı bir risk oluşturma ihtimali hesaba katıldığında, hukuki düzenlemelerin oluşturulmasında paniğe gerek bırakmayan titiz bir yaklaşımın önemi daha iyi anlaş1lacaktır. Her şeye rağmen, yapay zekâ sistemlerinin ve algoritma teknolojilerinin geliştirilmesinin, bireysel hak ve özgürlüklerin korunmasıyla uyum içinde gerçekleşmesi gerektiği de unutulmamalıdır.

61 Konuyu vergi hukuku boyutuyla inceleyen Gedik; Türkiye'nin her ne kadar bu teknolojik gelişmeleri geriden takip etse de, hukuki düzenlemeler konusunda ihtiyaçları tespit ve sektörel gelişmeleri takip eden bir politika ile çağı yakalayabileceğini; bunun bir zorunluluk olduğunu çünkü gelişen teknolojiler düzenlemelerin öngördüğü senaryoların dışına çıkmaya başladığını ve ilerleyen dönemlerde birçok değişikliğin olmasının kaçınılmaz göründüğünü belirtmiştir, GEDİK, Gülşen, "Robotlara Karşı Gerçek Kişilerin Korunması Açısından Robot Vergisi Önerisi”, Marmara Üniversitesi Hukuk Fakültesi Hukuk Araştırmaları Dergisi, Cilt: 26, Sayı: 1, Haziran 2020, s. 45. 


\section{YAPAY ZEKÂNIN İDARE HUKUKU BOYUTU}

Easterbrook'un "Cyberspace and the Law of the Horse" isimli ünlü makalesinde "law of the horse" benzetmesi ${ }^{62}$ çerçevesinde, hukukun yapay zekâyı ciddiye almasını reddetmek kolay olsa da yapay zekâ hukukla ilgili bilinenleri dönüştürmeye başlamıştır. İdare hukuku bu dönüşümün bir parçası olduğu için, yapay zekânın idare hukukuna dair kavramlar ve kurumlar üzerindeki etkilerini ele almaya çalışacağız.

\section{A. Yapay Zekânın, Organik ve Fonksiyonel Anlamda İdare Üzerindeki Etkileri}

Yapay zekânın idare hukukuna etkilerini, organik ve fonksiyonel bakımından iki ayrı pencere açarak incelemeye ve değerlendirmeye çalışacağız.

\section{Yapay Zekâ ve Organik Anlamda İdare Üzerinde Etkileri}

$\mathrm{AB}$, yapay zekâya ilişkin hukuki çerçevenin oluşturulması yönünde birçok çalışma başlatmıştır. Yukarıda yer verdiğimiz Yapay Zekâ Üzerine Beyaz Kitap raporunda, özel sektöre ve kamu sektörüne yönelik yapay zekâ kullanımına yönelik ilkeler oluşturma, riskli sistemlere yönelik uygulamalar getirme gibi dijital dönüşümle ilgili fikir ve eylem planını açıklamıştır. Yapay zekâya ilişkin hukuki düzenleme önerilerinden biri de Yapay Zekâ Geliştirme Yasası'nın (Artificial Intelligence Development Act/AIDA) hazırlanarak, yapay zekâ sistemlerinin güvenliğini onaylamakla görevli bir kurum oluşturulması ve bu kurumun bir sertifikasyon sistemini yürütmesidir. Periyodik olarak

62 Yargıç Easterbrook, siber hukuk ile ilgili eleştirisini “at hukuku” benzetmesi ile yaparak, belki saldırgan belki de mizahi bir yaklaşımla hukuk fakültelerinin at hukuku üzerine bir kursa ihtiyaç duyduklarından daha fazla siber hukuk kursuna ihtiyaç duymadıklarını savunmuştur, EASTERBROOK, Frank H., "Cyberspace and the Law of the Horse", University of Chicago Legal Forum, 1996, s. 207-216, https://chicagounbound.uchicago.edu/cgi/viewcontent.cgi?article=2147\&context=journal articles (Erişim Tarihi: 12.11.2020). Bunun üzerine akademisyen Lessig karşı bir makaleyle hukuk ve siber uzamın birbirine bağlandığına ve internetin hukuku etkilediğine işaret ederek karşı bir eleştiri getirdi. LESSIG, Lawrence, "The Law of the Horse: What Cyberlaw Might Teach", Harvard Law Review, Volume: 113, No. 2, 1999, s. 501-549, https://www.jstor.org/stable/1342331 (Erişim Tarihi: 12.11.2020). $\mathrm{Bu}$ ünlü Easterbrook-Lessig tartışmasından günün sonunda, Lessig’in görüşünün galip geldiği görülmektedir. 
güncellenecek kurallarla kurumun, yapay zekânın araştırılmasına ve geliştirmesine müdahale etme gücünün sınırları da belirlenecektir. Bu kurumun bağımsız bir idari yap1 olması ve üyelerinin yürütme organı tarafından atanması önerilmiştir ${ }^{63}$. Yine başka bir çalışmada kamu yönetimi içinde, yapay zekâ sistemlerinin geliştirilmesinin garantörü olarak hareket edebilecek bağımsız bir otoritenin kurulması ihtiyacının olduğundan bahsedilmiştir ${ }^{64}$. Nitekim, AB'nin Yapay Zekâ Kanunu taslağında, üye ülkeler için ulusal denetim otoritelerinin (national supervisory authorities) oluşturulması öngörülmüş ve “Avrupa Yapay Zekâ Kurulu” (European Artificial Intelligence Board) düzenlenmiştir.

Türk hukukunda yapay zekâ ile idarenin bir ilişki kurmasını sağlayacak organik anlamdaki girişim, Cumhurbaşkanlığına bağlı Dijital Dönüşüm Ofisinin (“Ofiss”) oluşturulmasıdır. 1 numaralı Cumhurbaşkanlığı Teşkilatı Hakkında Cumhurbaşkanlığı Kararnamesi'nde ${ }^{65}$ ("CBK”) dijital dönüşüm, "dijital teknolojilerin kullanımı ve geliştirilmesi yoluyla ekonomik ve sosyal refahın artırllmasına yönelik insan, iş süreçleri ve teknoloji unsurlarında gerçekleştirilen bütüncül dönüşümü̈” olarak tanımlanmıştır (m. 526/1-c). 48 numaralı CBK ${ }^{66}$ ile 1 numaralı CBK' da yer alan Ofis' in görev ve yetkileri düzenlenmiştir. Yapay zekâya da atıf yapılan görevlerin iki boyuta sahip olduğu görülmektedir: İlki hem organik açıdan hem de sunulan kamu hizmetleri açısından, dijital dönüşümün yol haritasının hazırlanmasıdır. Diğeri ise dijital dönüşüme dair stratejiler geliştirmede özel sektöre destek sağlanması, bu alanda idarenin denetimine yönelik projeler geliştirilmesi ve dijital teknoloji yetkinliklerinin geliştirilmesine katkı sağlanması olarak özetlenebilir.

1 numaralı CBK'da, Ofis Başkanının, "Kamu Dijital Dönüşüm Lideri” olarak isimlendirildiği göze çarpmaktadır. Ofis'in hizmet birimleri arasında "Büyük Veri ve

63 SCHERER, 2015, s. 393 vd.

64 Böyle bir otoriteye, "yart yasama" veya "yarı adli" yetkilerin hatta, şu anda mevcut kamu otoritelerine açık bir şekilde atfedilemeyen çeşitli işlevlerin verilmesi de önerilmiştir, BASSINI Marco/GREGORIO Giovanni De/MACCHIA Marco vd., The Ethics and Law of AI, La Fondazione Leonardo - Civiltà delle Macchine, yy., s. 68, https://fondazioneleonardocdm.com/site/assets/files/2450/fle1 booklet conferenza eng gar 311019.pdf (Erişim Tarihi: 12.11.2020).

65 RG. T. 10.07.2018, S. 30474.

66 Cumhurbaşkanlığı Teşkilatı Hakkında Cumhurbaşkanlığı Kararnamesinde Değişiklik Yapılmasına Dair Cumhurbaşkanlığı Kararnamesi, RG. 24.10.2019, S. 30928. 
Yapay Zekâ Uygulamaları Dairesi Başkanlığı” yer almaktadır. Söz konusu Başkanlığın görevleri, kamuda yapay zekâ uygulamalarının kullanılması ve geliştirilmesi etrafında sıralanmıştır. Yapay zekâya ilişkin oluşturulacak yapıların bağımsızlıklarına dair görüşlere yukarıda yer vermiştik. Bu anlamda ofislerin, söz konusu bağımsız yapıya sahip olup olmadıkları da tartışılabilir. Konumuzu aşmamak adına, bağımsızlık meselesinin idari özerklik olarak anlaşılması gerektiği, ancak ofislerin ayrı kamu tüzel kişiliğe sahip olmalarına rağmen özerklik açısından oldukça sorunlu düzenlemelere tabi olduğu belirtilmelidir.

Öte yandan 1 numaralı CBK'da Sanayi ve Teknoloji Bakanlığının görevleri arasında; “... büyük veri, yapay zekâ, siber güvenlik gibi kritik alanlarda bireylerin ve işletmelerin ar-ge ve üretim yetkinliklerinin artırlması amacıyla politika önerileri ve stratejiler oluşturmak, belirlenen politika ve stratejilerin uygulanmasını sağlamak, ilgili alanlarda ar-ge ve yatırım faaliyetlerini ve girişimleri desteklemek, ilgili alanlara ve desteklere dair düzenleme ve denetlemeler yapmak" sayılmıştır (m. 385).

Ayrıca Bakanlığa bağlı Milli Teknoloji Genel Müdürlüğünün “... büyük veri ve yapay zekâ gibi konularda bireylerin ve işletmelerin yetkinliklerinin artırılmasına ve bu teknolojilere dayalı akıllı sistemlerin geliştirilmesi ve yaygınlaştırılmasına yönelik tedbirleri almak, destek ve teşvik programları uygulamak, program ve projeler yürütmek" şeklinde bir görevi de bulunmaktadır (m. 388/A). Yine Bakanlığa bağlı Stratejik Araştırmalar ve Verimlilik Genel Müdürlüğünün, veri yönetimi ve veri analitiği uygulamaları kapsamındaki görevlerine 1 numaralı CBK' da yer verilmiştir (m. 388/B).

İdare açısından büyük veri ve yapay zekâ uygulamalarının etkin olarak kullanımını sağlamaya yönelik olarak Ofis tarafından çeşitli projeler başlatılmıştır. Örneğin, “Türk Beyin Projesi” ile, beyin MR görüntüleri üzerinde çeşitli analizler yapay zekâ tabanlı sistemler sayesinde gerçekleştirilmekte, yapay zekâ destekli bu sistem analiz sonuçlarına göre, çekilen MR görüntüleri öncelikle doktorların değerlendirmesine sunulmaktadır ${ }^{67}$. Böylece, acil müdahaleye ihtiyaç duyabilecek hastalara daha hızlı bir şekilde müdahale edilerek, çeşitli komplikasyonların oluşma ihtimali azaltılabilecektir. Sağlık kamu

67 Dijital Dönüşüm Ofisi, Türk Beyin Projesi (TBP), https://cbddo.gov.tr/projeler/tbp/ (Erişim Tarihi: 12.11.2020). 
hizmeti boyutuyla hizmetin iyi ve zamanında işlemesi için yapay zekâ kullanımı önem taşımaya başlamıştır. Japonya, ABD, Çin gibi ülkelerde olduğu gibi ${ }^{68}$ ülkemizde de yapay zekâ politikalarının yürütülmesinde idarenin içinde uzmanlık gerektiren birimlerin oluşturulması ve bu teknolojinin gündelik hayata geçirilmesinde yani kamu hizmetlerinde kullanılmasının altyapısını ve koordinasyonunu sağlamak üzere hukuki zeminde çeşitli girişimlerde bulunulmuştur. $\mathrm{Bu}$ anlamda Ofis'in yapay zekâ alanında yürüteceği çalışmaların hem idareyi hem de idare edilenleri etkileyecek şekilde ilerleyeceğine dair beklenti içinde olmak gerekir.

\section{Yapay Zekâ ve Fonksiyonel Anlamda İdare Üzerinde Etkileri}

Yapay zekâ, idarenin yürüttüğü faaliyetler üzerinde yenilikler getireceği gibi, idari işlem ve yapılış usulü üzerinde değişimler yaratacak bir kullanım alanına sahip olmaya başlamıştır. Bu doğrultuda, fonksiyonel idare ve yapay zekâ arasındaki etkileşim iki başlık halinde değerlendirilecektir.

\section{a. İdarenin Düzenleme ve Denetleme Faaliyetleri ile Yapay Zekânın Kesişimi}

Bir görüşün belirttiği üzere, teknolojik gelişmeler bazı sorunlara ve tehlikelere yol açmakla birlikte, nasıl sırf virüs yayılıyor diye internet kapatılamayacak ve internetten vazgeçilemeyecekse $^{69}$, yapay zekâlar için de aynı durumdan bahsedilebilir. Ancak devletlerin, yapay zekâ alanındaki büyük kurumsal yapılara (Microsoft, Apple, Facebook, Google gibi) karşı muhtemelen tarihte ilk kez bu ölçekte bir dezavantaja sahip olduğu da belirtilmektedir ${ }^{70}$. Dolayısıyla bu dinamik alanın temposuna yetişmek için hukukun,

68 TAMER, Halil Yasin/ÖVGÜN, Barış, "Yapay Zeka Bağlamında Dijital Dönüşüm Ofis”, Ankara Üniversitesi Siyasla Bilgiler Fakültesi Dergisi, Cilt: 75, Say1: 2, 2020, s. 790 vd.

69 KURZWEIL, Ray, “The Law of Accelerating Returns", Alan Turing: Life and Legacy of a Great Thinker, Ed. TEUSCHER, Christof, Heidelberg, Springer, 2004, s. 411, https://doi.org/10.1007/978-3-662-05642-4 16 (Erişim Tarihi: 16.11.2020).

70 GUIHOT, Michael/MATTHEW, Anne F./NICOLAS Suzor, "Nudging Robots: Innovative Solutions to Regulate Artificial Intelligence", Vanderbilt Journal of Entertainment \& Technology Law, 
özellikle idare hukukunun karşılaşacağı belirsizlikler vardır. Bu tempoda, yapay zekânın toplumsal hayatı kapsamaya başlaması ile kanun koyucunun belki de anayasa koyucunun temel düzenlemeler yapması ve bu konuyu temel ilkelere bağlaması gerekecektir. Esnek hukuk dediğimiz, öz düzenleme gibi hukuki enstrümanlar, belirli faydalar sağlayacak ise de idarenin bu alanı düzenlemesi ve denetlemesine ilişkin ayrıntılı bir çalışma alanının oluşturulması, üstelik disiplinlerarası bir yaklaşımla hareket etmesi gerekmektedir.

Yapay zekâya ilişkin anayasada ve kanunlarda yer alacak temel kurallar ve ilkeler idarenin işlemleriyle somutlaşacaktır. $\mathrm{Bu}$ anlamda idare hukukunun konusuna giren pek çok alanda olduğu gibi ikincil mevzuat oldukça önem taşıyacaktır. Yapay zekânın kendisinin, eylemlerinin ve belki de işlemlerinin düzenlenmesi ve denetlenmesi bugünden çok uzak bir düşünce olarak görülmemelidir. On sene öncesinde hayal edilemeyecek birçok bilimsel gelişmeye bugün temas ettiğimiz ortadadır ${ }^{71}$. Nitekim AB'nin Yapay Zekâ Kanunu taslağında, risk temelli bir yaklaşımla yapay zekâ sistemlerinin sağlayıcılarının ve kullanıcılarının yükümlülüklerine ilişkin kurallar belirlenmiş, üye devletiler için uyulması gereken esaslara yer verilmiştir. Taslakta, dört risk grubu olarak; kabul edilemez risk, yüksek risk, sınırlı risk ve asgari risk (m. 5.2.2) belirlenmiş ve bu risk gruplarına yönelik kurallar oluşturulmuştur. Taslakta, yapay zekâ sistemleri üzerindeki kolluk faaliyetine yönelik olarak ex ante (izin/sertifikasyon) ve ex post denetim (gözetim/inceleme) araçlarına yer verilmiş, kurallara uymamanın hukuki sonuçları (yaptırımlar) da öngörülmüştür.

İdare hukukunun uygulama alanı her geçen gün çeşitlenmekte ve teknolojik gelişmelerle kendi içinde özelleşmeye doğru gitmektedir ${ }^{72}$. Dijitalleşmenin artması şimdiden idare hukukunun uğraş alanına farklı konuların girmesine sebep olmuştur;

Forthcoming, Volume: 20, Issue: 2, 2017, s. 31 vd., https://ssrn.com/abstract=3017004 (Erişim Tarihi: 12.11.2020).

71 Yuval Noah Harari, "Homo Deus: A Brief History of Tomorrow” adlı kitabında bilimin, algoritmaya ve veriye yönelerek gelişeceğini, algortimaların her şeyin yerini alacağını, yapay zekânın biyoteknoloji ile birleşeceğini, zekânın bilinçten ayrılacağını ve yüksek zekâlı algoritmaların bizim kendimiz hakkında bildiğimizden daha fazlasını bileceğini öngörmektedir. HARARİ, Yuval Noah, Homo Deus: Yarının Kısa Bir Tarihi, Çev. TANELİ, Poyzan Nur, İstanbul, Kolektif Kitap, 2016, s. 293 vd.

72 Robotik alanındaki gelişmelerin ABD'deki idare hukuku ve kamu kurumlarına etkisi için bkz. CALO, Ryan, "Robotics and the Lessons of Cyberlaw", California Law Review, Volume: 103, No. 3, 2015, s. 555-558, http://dx.doi.org/10.2139/ssrn.2402972 (Erişim Tarihi: 12.11.2020). 
dijital ekonomi, e-ticaret, sanal platformlar, kripto para birimleri gibi birçok kavram, idarenin düzenleyici ve birel işlemleriyle düzenleme ve denetleme faaliyetinin konusu haline gelmiştir. Özellikle ekonomik anlamda dijitalleşmenin yarattığı sonuçlar, bu alandaki idari faaliyetlerin çeşitlenmesine neden olmuştur. Çünkü yeni teknolojiler homo economicus'u machina economica' ya dönüştürmüştür.

ABD'nin Nevada eyaletinde sürücüsüz (otonom) otomobillere ilişkin olarak 2011 yılında yapılan hukuki düzenleme bu alandaki ilklerden biri olarak kabul edilebilir ${ }^{73}$. Bu düzenlemede, bir devlet kurumu olan Nevada Ulaştırma Departmanına (Nevada Department of Transportation), GPS sensörleri ve lazerler gibi yapay zekâ ve sensörler kullanarak otonom araçların test edilmesini, güvenliğini ve nihayetinde yollarındaki varlığını düzenlemek için kural koyma yetkisi verilmiştir. Otonom sürüş sistemleri veya otonom araçlarla ilgili belirli teknolojilere ilişkin düzenlemeleri kabul etmeye veya şartlar getirmeye yetkili tek kurum olarak Departman kabul edilmiştir; yerel yönetimin vergi, harç veya diğer gereklilikleri uygulaması yasaklanmıştır ${ }^{74}$. Bu arada, Ulusal Karayolu Taşımacılığı Güvenliği İdaresi (National Highway Transportation Safety Administration), aracı kullanandan ziyade, sürücüsüz araç sisteminin bir aracın “sürücüsü” olarak kabul edilebileceğini belirlemiştir"

Ülkemizde ise insansız hava araçlarına (İHA) yönelik bir düzenlemenin, idare hukuku açısından adsız düzenleyici işlem olan bir talimat ile yapıldığını görüyoruz. Sivil Havacılık Genel Müdürlüğü tarafından yayımlanan “İnsansız Hava Aracı Sistemleri Talimatı (SHT-İHA)"; Türk Hava Sahasında uçacak İHA'ları (insansız hava aracı), ilgili sistemleri, bunları ithal edecek, satışını yapacak, işletecek ya da kullanacak gerçek ve tüzel kişileri, bu kapsamda görev alacak personeli, İHA ekibini ve hava sahası kullanımı ile verilecek hava trafik hizmetlerini kapsamaktadır. İHA; insansız hava aracı sisteminin bir bileşeni olarak işletilen, aerodinamik kuvvetler aracılığıyla sürekli uçuş yapma yeteneğinde olan, üzerinde pilot bulunmaksızın uzaktan İHA pilotu tarafından kontrol

\footnotetext{
73 Nevada Revised Status Chapter 4822-Autonomous Vehicles, https://www.leg.state.nv.us/nrs/nrs482a.html (Erişim Tarihi: 12.11.2020).

74 Nevada Revised Status Chapter 482A.110.

75 STONE/BROOKS/BRYNJOLFSSON vd., 2016, s. 45.
} 
edilerek veya otonom operasyonu İHA pilotu tarafından planlanarak uçurulan ya da havada kalabilen hava aracı şeklinde tanımlanmıştır. Talimat'ta, İHA'lara yönelik, izin, denetim, sigorta, sorumluluk, idari tedbir ve yaptırım hususları düzenlenmiştir. Belirli kategorideki İHA'ların idare tarafından oluşturulan internet tabanlı “Kayıt Sistemi”ne kaydedileceği öngörülmüştür.

Özel kişilerin faaliyetleri yanında devletin kendisi de eğitim, çevre, sağlik, ulaştırma, savunma, enerji gibi birçok kamu hizmetinde yapay zekâdan yararlanabilecektir ${ }^{76}$. İdarenin yapay zekâ ile doğru bir başlangıç yapması için şu stratejiler önerilmiştir; yapay zekâyı hedeflere dayalı, vatandaş merkezli bir programın bir parçası haline getirmek, vatandaş girdisi almak; mevcut kaynakların üzerine inşa etmek, veri hazırlıklı olmak ve gizlilik içinde dikkatli olmak; etik riskleri azaltmak ve yapay zekâ tabanlı karar vermekten kaçınmak, çalışanları büyütmek ${ }^{77}$. Yapay zekâ bugün çalışma hayatında hız ve maliyet açısından gerçek kişi çalışanların yerini almaya başlamış ve yeni mesleklerin kapısını aralamıștır. İdare istihdam politikasında bu değișimlerinden yararlanacak ve kamu personeli tercihini yapay zekâlara yönlendirebilecektir ${ }^{78}$. Ülkemizde internet üzerinden yürütülen birçok işlemin yapay zekâ uygulamalarıyla desteklenmesi durumunda, elektronik devletin (e-devletin) akıllı devlete (a-devlete) evrilmesi söz konusu olacaktır.

76 Örneğin etkileşimli makine öğretmenlerinin fen, matematik, dil ve diğer disiplinleri öğretmek için öğrencilerle eşleştirilmesi; doğal dil öğrenme ile çevrimiçi öğrenimin artması; bu teknolojilerin sınıfta ve evde kullanılması ve yüz yüze öğrenimle anlamlı bir şekilde entegre edilmesi gibi birçok gelişmenin eğitim alanında ortaya çıkmaya başladığı belirtilmektedir, STONE/BROOKS/BRYNJOLFSSON vd., 2016, s. 31.

77 MEHR, Hila, Artificial Intelligence for Citizen Services and Government, 2017, s. 10, https://ash.harvard.edu/files/ash/files/artificial intelligence for citizen services.pdf (Erişim Tarihi: 12.11.2020).

78 Executive Office of the President National Science and Technology Council Committee on Technology, Preparing for the Future of Artificial Intelligence, 2016, s. 10, 14-16, https://obamawhitehouse.archives.gov/sites/default/files/whitehouse files/microsites/ostp/NSTC/prep aring for the future of ai.pdf (Erişim Tarihi: 12.11.2020). 


\section{b. İdari Usul ve İdari İşlem Açısından Yapay Zekânın Rolü}

İdarenin karar alma süreçlerinde yapay zekâyı kullanması, idari işlem teorisini ve idare yargıcının yargısal denetim kriterlerini etkileyecektir. Örneğin belirli bir algoritmaya tabi yapay zekâdan yararlanılarak yapılan idari işlem, yargı önüne taşındığında daha önceden karşılaşılmamış sorunlar idare yargıcı tarafından değerlendirilecektir. Yakın zamanda idari yargıya yansıyan ve konuyla bağlantılı bir uyuşmazlık kamuoyuna yansımıştır ${ }^{79}$. Karardaki olaya göre, İtalya'da 2016 yılından bu yana bir dizi parametreye dayanan ve öğretmenlerin coğrafi olarak nereye atanacağına "karar veren" bir algoritma kullanılmaktadır. Bu algoritmanın yaptığı atamalar sebebiyle öğretmen sendikaları, iç işleyişin ayrıntılarını ve algoritmaya erişim talepleri için bakanlığa başvurmuşlardır. Bakanlık, algoritmayı sağlayan yazılım satıcısından algoritmanın nasıl çalıştığını açıklayan bir metin hazırlamasını istemiştir. Ancak, özet şeklindeki bu açıklamanın genel bulunması üzerine sendikalar, bakanlıktan algoritmanın kaynak koduna erişiminin sağlanmasını istemiştir. Bakanlık ise bu talebi reddetmiş ve birkaç öğretmen sendikası bakanlığa dava açmıştır.

Anılan olayda, Lazio Bölge İdare Mahkemesi (Tribunale Amministrativo Regionale Lazio/TAR Lazio), bireylerin haklarını veya meşru menfaatlerini etkileyebilecek idari bir süreci yürütmek için kullanıldığında, bir algoritmanın ayrı bir "idari belge" olarak görülmesi gerektiğine, bu nedenle olayda özel kişinin fikri mülkiyet hakkının ihlal edilmeyeceğine ve kaynak kodun erişilebilir olması gerektiğine karar vermiştir $^{80}$. Mahkeme, yazılım satıcısının açıklamasının sunulmasına yönelik bakanlık girişimini yeterli görmemiştir. Mahkeme, şeffaflığg neyin oluşturduğuna da karar vermiştir. Mahkemeye göre ancak kaynak koduna tam erişim sayesinde, algoritmanın dahil edildiği süreçlerin geçerliliği, hataların varlığı ve algoritmanın ilgili kararların doğru bir şekilde uygulanması gereken kriterlere bağlılığı doğrulanabilecektir. Söz

79 TAR Lazio, chamber III bis, 21.03.2017, No. 3742. "AI technology and government decision making recent Italian rulings", 29.06.2020, https://iclg.com/ibr/articles/10731-ai-technology-and-professionaldecision-making-recent-italian-rulings (Erişim Tarihi: 12.11.2020).

80 Konuyla ilgili değerlendirmeler için bkz. COSTANTINO, Fulvio, "Public Officials and the Design of Algorithms. Lessons from the Italian Experience", European Review of Digital Administration \& Law-Erdal, Volume: 1, Issue: 1-2, 2020, s. 143-155. 
konusu algoritmanın idarenin belirli bir amaç doğrultusunda kullanması için özel olarak oluşturulduğu düşünüldüğünde, özel hukuk kişisinin yapay zekâya ilişkin telif haklarının şeffaflık ilkesi çerçevesinde denetlenebilir olup olmayacağına ve kamu yararı amacıyla telif hakkının sınırlanıp sınırlamayacağına dair idare hukuku dışındaki hukuk dallarını ilgilendiren tartışmalar da doğabilecektir. TAR Lazio kararı doğrultusunda, idari işlemin yapılış usulü ile ilgili süreçlere dahil olan yapay zekâ ve "dijitalleşen idari usul" karşısında, idari usulün şeffaflaşması gerekliliği bariz bir şekilde karşımıza çıkacaktır.

Yapay zekâ yazılımının, bir idari işlem olarak kabul edilip edilemeyeceğinin de yeni açılacak konu başlıklarından biri olduğunu düşünmekteyiz. Dijital işleyen bir idari prosedürün parçası olan algoritmanın, doğrudan idari işlem olarak değerlendirilip değerlendirilemeyeceği tartışması uzun vadede doğacaktır. Burada farklı senaryolar geliştirilebilir: Doğrudan yapay zekâ algoritmasının verdiği kararla idari işlem tesis edilmesi, idarenin takdir yetkisini azaltacaktır. Böylece, idarenin takdir yetkisine yapay zekânın etkisinin incelenmesi yönünden, daha ayrıntılı belki de yerindelik denetimine uzanan bir yargı denetimi söz konusu olacaktır. İdarenin bağlı yetki içinde olduğu konularda ise yapay zekâ algoritmasının idarenin iradesinin yerini alması mümkün olacaktır. Tamamen dijital bir idari prosedürün hâkim olduğu kimi koşullarda, yapay zekâ algoritmasının idari işlem (“otonom idari işlem”) yapmasının uzak bir ihtimal olmadığı ifade edilebilir. Nitekim Alman Genel İdari Usul Kanunu'nda (Verwaltungsverfahrensgesetz/VwVfG) 2016 y1lında, insan müdahalesinin ve iradesinin olmadığı tam otomatik bir süreçle (vollständig durch automatische) idari işlem tesis edilmesi ("otomatikleştirilmiş idari işlem”) öngörülmüştür. Madde hükmüne göre, yasanın izin vermesi ve idarenin herhangi bir takdir yetkisinin veya bir takdir marjının olmaması koşuluyla, tamamen otomatik-dijital bir yolla idari işlem oluşturulabilir ( $§ 35 \mathrm{a}$ $\mathrm{VwVfG})^{81}$.

Diğer taraftan, idari prosedür içindeki yapay zekâ sisteminin "idari ajan” olarak nitelendirilmesi de bir olasılıktır. Bu durumda "sanal kamu görevlisinin" işlemi, idari

81 Konuyla ilgili değerlendirmeler için bkz. BUOSO, Elena, "Fully Automated Administrative Acts in the German Legal System", European Review of Digital Administration \& Law-Erdal, Volume: 1, Issue: 1-2, 2020, s. 113-122. 
usulün bir parçası olarak nihai idari işlemi oluşturan bir zincir işlem olarak ele alınabilecektir. Bu halde ise yapay zekânın işleminin icrai olarak hukuki sonuç doğurduğu kabul edilip dava konusu edilebilmesi söz konusu olacaktır. Yine de eklemek gerekir ki yapay zekânın hukuki kişiliğinin tanınıp tanınmaması yönündeki gelişmelerle birlikte, belirttiğimiz olasılıklara farklı sonuçlar bağlanması mümkün olacak ve öngörülmeyen başlıklar açılacaktır. Mevcut durumda yapay zekânın bir araç olarak kabul edilmesi halinde dahi, idare hukukundaki etkileri ortaya çıkmaya başlamıştır.

\section{B. Yapay Zekânın, İdarenin Sorumluluğuna Getireceği Yaklaşımlar}

Yapay zekâ uygulamaları, dijital danışman, ses ve yüz tanıma, video yaratma, eposta filtreleme, dolandırıcılık önleme, pazarlama yöntemleri, içerik yönetimi gibi günlük hayatın içinde kullanılan otonom araçlarla hayatımızda giderek daha fazla yer edinen bir teknolojidir ${ }^{82}$. Yukarıda belirttiğimiz üzere yapay zekâ her bilimsel gelişmede olduğu gibi farklı sorunların da taşıyıcısı olmuştur. Robot kaynaklı ilk bilinen vakada, 1979 yılında Michigan'da bir otomotiv parçaları fabrikasındaki robot (ilk katil robot) bir fabrika işçisini öldürmüş ve açılan davada robotu tasarlayan üretici firmanın işçinin ailesine tazminat ödenmesine karar verilmiştir ${ }^{83}$.

Yapay zekâ ilerledikçe ve "bot”lar ${ }^{84}$ bir bilgisayar donanıma göre daha fazla işlev gördükçe, sorumluluk meselesi daha karmaşık hale gelmektedir. Örneğin 2016 yılında otopilot konumunda çalıştırılan Tesla otomobilinin traktör römorkuyla çarpıştığı kazada, otomobil sürücüsü hayatını kaybetmiştir. Bu kaza, sürücüsüz (otonom) aracın karıştığı

82 Örneğin bir çalışmada otonom depo robotlarının, insanların Zappos ve Amazon.com dahil olmak üzere birçok çevrimiçi perakendecinin siparişlerini yerine getirmesine yardımcı olduğu; bu robotların, envanter sistemi tarafından merkezi olarak koordine edilip bağımsız olarak çalıştığı; birbirlerinden kaçındıklarından ve depodaki ürünlerin depolanma yerlerini müşteri talebine göre yeniden yapılandırdıklarından bu robotların kendi zihinsel yapılarına sahip göründüğü belirtilmiştir, RICHARDS, Neil M./SMART, William D., How Should the Law Think About Robots?, 2013, s. 9, http://ssrn.com/abstract=2263363 (Erişim Tarihi: 12.11.2020).

83 BIZONY, Piers, "Focus: \#1 The First Law: A Robot May Not Injure a Human Being, or, through Inaction, Allow a Human being to Come to Harm", Engineering \& Technology, Volume: 10, No. 6, 2015, s. 52-53, http://dx.doi.org/10.1049/et.2015.0621 (Erişim Tarihi: 12.11.2020).

84 Robot kelimesinin kısaltılmışı olan bot, fiziki bir varlık olmayan ve verilen görevi/komutu yerine getiren yazılımların internet üzerindeki versiyonudur. 
ilk ölümlü kaza olarak kaydedilmiştir. Yapılan incelemeler sonucunda, kazanın olası nedenleri römork sürücüsü ve otopilot arasında paylaştırılırken, Tesla için herhangi bir hukuki sorumluluk çıkarılmamıştır ${ }^{85}$. Yakın zamanda da Tesla'nın sürücüsüz otomobili, ABD'de ölümlü bir kaza yapmıştır ${ }^{86}$. Yine 2018 y1lında Uber'in sürücüsüz otomobili kaza geçirmiş ve bir kişinin ölümüne yol açmış, ancak Uber de sorumlu bulunmamıştır ${ }^{87}$. İnsanlar tarafından tasarlanan yapay zekânın ırkçı önyargılarla depolanması halinde aldığı haksız kararların sonuçları şimdiden tartışılmaktadır. Savunma sahasında silahlar ve tıp alanında sağlık uygulamalar gibi birçok alanda farklı sorunlar ortaya çıkacaktır. Sorumluluğun kime ait olduğu belirtilmemekle birlikte ABD'de 2016 yılında açıklanan bir araştırmada, 2008 ve 2013 yılları arasındaki cerrahi operasyonlarda hayatını kaybeden 144 kişinin ölümünün robotlardan kaynaklandığı öngörülmüştür ${ }^{88}$. Diğer bir örnekte, 2016 y1lında Microsoft'un sohbet uygulaması olan Twitter üzerindeki TayTweets'in, tanıtıldığı andan 24 saat içinde kadın düşmanı ve ırkçı mesajlar atmaya başlaması nedeni ile bu uygulama hemen durdurulmuştur ${ }^{89}$. Asimov'un “Üç Robot Yasası"nın" ${ }^{90}$ belirlediği

85 “Tesla's 'Autopilot' Shares Blame in 2016 Fatal Crash, U.S. Investigators Say", The Wall Street Journal, 12.09.2017, https://www.wsj.com/articles/teslas-autopilot-shares-blame-in-2016-fatal-crashu-s-investigators-say-1505233891 (Erişim Tarihi: 14.05.2021).

86 “Two Die in Tesla Car Crash in Texas with 'No One' in Driver's Deat, Police Day", The Guardian, 19.04.2021, https:/www.theguardian.com/technology/2021/apr/19/two-die-in-tesla-crash-no-one-indrivers-seat-police (Erişim Tarihi: 09.05.2021).

87 “Uber 'Not Criminally Liable' for Self-Driving Death", BBC, https://www.bbc.com/news/technology47468391 (Erişim Tarihi: 12.11.2020).

88 "Adverse Events in Robotic Surgery: A Retrospective Study of 14 Years of FDA Data”, 2016, https://www.ncbi.nlm.nih.gov/pmc/articles/PMC4838256/ (Erişim Tarihi: 12.11.2020).

89 Bu olayla ilgili inceleme için bkz. NEFF, Gina/NAGY, Peter, "Talking to Bots: Symbiotic Agency and the Case of Tay", International Journal of Communication, Volume: 10, 2016, s. 4915-4931, https://ijoc.org/index.php/ijoc/article/view/6277 (Erişim Tarihi: 12.11.2020).

90 ABD’li biyokimya profesörü ve bilim kurgu yazarı Isaac Asimov, "I, Robot” isimli eserinin yer verdiği “Three Laws of Robotics” (Üç Robot Yasası) ile robot-insan ilişkisinin anayasasını oluşturmuştur;

1. Bir robot, bir insana zarar veremez ya da hareketsiz kalarak bir insanın zarar görmesine neden olamaz.

2. Bir robot, Birinci Yasa ile çeliştiği durumlar dışında, insanlar tarafından verilen emirlere uymalıdır.

3. Bir robot, birinci ve ikinci yasalarla çelişmediği sürece kendi varlığını korumak zorundadır.

Asimov, üç robot yasasına yeni bir yasa daha ekledi ve bunu "0" sayısı olarak belirleyerek "sıfirıncı yasa"yı oluşturdu;

0. Bir robot, insanlığa zarar veremez ya da insanlığın zarar görmesine seyirci kalamaz. 
ilkelerin ihlalini somutlaştıran bu olaylar, yapay zekânın sorumluluğu ve robot hakları gibi konuları çözmeleri için hukukçuların gündemine dahil olmuştur.

Yukarıda örnekleri verilen meseleler hakkında, medeni hukuk ve ceza hukuku başta olmak üzere farklı hukuk disiplinleri çerçevesinde görüşler sunulmaktadır. Örneğin Türk hukukunda, medeni hukuk boyutuyla akdi sorumluluk ve yoğunlukla da akit dışı sorumluluk (adam çalıştıranın kusursuz sorumluluğu, ev başkanının sorumluluğu, tehlike sorumluluğu vs.) çerçevesinde konunun ele alındığ 1 görülmektedir ${ }^{91}$. Yapay zekânın kullanıldığ 1 alanlara göre de hukuki değerlendirmeler farklılaşacaktır ${ }^{92}$. Nitekim Avrupa Parlamentosu, etik, medeni sorumluluk, fikri haklar, ceza hukuku, eğitim, kültür gibi alanlarda yapay zekâ ile ilgili ayrı düzenlemeler yapmaya devam etmektedir.

Mevcut aşamada yapay zekânın tepkilerinin ve sosyal ilişkilerdeki katılımının tamamen insan davranışına bağlı olduğu; dolayısıyla algoritmaları tasarlayan, çalıştıran veya manipüle eden insanların sorumluluğuna odaklanmanın daha kolay olduğu ifade edilebilir. Ancak, makine öğrenimi alanındaki araştırmalar, yapay bir vicdanın hızlı bir şekilde elde edildiğine de işaret etmektedir. Örneğin cezai yaptırımlar ele alındığında, daha önce mevcut olanların hiçbirinin yapay zekâ sistemlerine uygulanamayacağı ifade edilmiştir $^{93}$. Yine öz farkındalığa sahip olan yapay zekâlar için de hukukta öngörülen

ASIMOV, Isaac, "Runaround", Astounding Science Fiction, 1942; ASIMOV, Isaac, Robots and Empire, 1st ed., Doubleday Books, 1985, aktaran, ALEXANDRE, 2017, s. 41.

91 AKKURT, Sinan Sami, "Yapay Zekânın Otonom Davranışlarından Kaynaklanan Hukukî Sorumluluk", Uyuşmazlık Mahkemesi Dergisi, Sayı: 13, 2019, s. 47 vd.

92 Sorumluluk meselesinde farklı ihtimallerle karşı karşıya kalındığı da malumdur. Örneğin eylem bir kodlama eksikliği ile sağlanmışsa, ürün kusur kuralları uygulanarak, tasarımcının ihmalden sorumlu tutulabilmesi muhtemeldir. Eylem tamamen yapay zekânın gelişen davranışından kaynaklanıyorsa, tasarımcının yapay zekâ adına sigorta yaptırarak kendisini muaf tutabilmesi de düşünülebilir. Tasarımcının, yapay zekânın verdiği zararları üçüncü şahıslara tazmin edecek araçlara sahip olmasını sağlayarak, sorumluluğunu ona devretmesi de bir öneri olarak ele alınabilir. Bir başka çalışmada sorumluluk konusunda getirilen öneriler arasında "ebeveyn modeli" göze çarpmaktadır. Buna göre, sorumluluk için ebeveyn modeli (bir tür dolaylı sorumluluktur) uygulanabilecek; ebeveynlerin çocuklarını eğittiği gibi öğrenme yeteneklerine sahip otonom robotlara da üreticinin ya da kullanıcının verdiği eğitimle davranışları öğretilecek; robotun eğitimi ne kadar uzunsa, öğretmenin/sahibinin sorumluluğu o kadar büyük olacaktır. Bkz., euRobotics, 2012, s. 55. Ancak çocuklar yetişkin olduktan sonra ebeveynler sorumlu tutulamaz. Peki yapay zekâlı robotlar söz konusu olduğunda bu nasıl değerlendirilecektir? Dolayısıyla konuyla ilgili sunulan birçok öneri geliştirilmeye açıktır.

93 STANILA, Laura, "Living in the Future: New Actors in the Field of Criminal Law - Artificial Intelligence", Legal Science: Functions, Significance and Future in Legal Systems II, Conference: The 7th International Scientific Conference of the Faculty of Law of the University of Latvia, 2019, s. 310, https://doi.org/10.22364/iscflul.7.2.24 (Erişim Tarihi: 13.11.2020). 
standart sorumluluk kurallarının bazı uyarlamalar doğrultusunda işletilebileceği ve yapay zekânın doğrudan sorumlu olabileceği belirtilmiştir (mutatis mutandis) ${ }^{94}$. Çalışmamızın kapsamını farklı hukuk disiplinlerindeki tartışmalara yaymamakla birlikte, güncel durumda, yapay zekâ sürecindeki katılımcılara sorumluluk riskinin nasıl dağıtılacağının, kamusal makam tarafindan öncelikle düzenlenmesinin gerekli olduğunu belirtebiliriz.

İdare hukuku açısından da yapay zekânın eylemlerinden dolayı gerçekleşen zararlarda sorumluluğun ne şekilde dağıtılacağı gündeme gelecektir. Örneğin, bir şirket tarafından üretilen yapay zekânın, idare tarafından satın alınarak bir kamu hizmetinde kullanılması ve bu hizmetten faydalanan bir kişinin yapay zekânın işlemi veya eylemi sebebiyle zarar görmesi halinde sorumluluğun kime yükletileceği meselesi doğmaktadır. Tabi burada idarenin sorumluluğu türleri ve idarenin sorumluluğuna ilişkin genel kurallar ilk başta yorumlanacaktır. Burada ilk gidilecek sorumluluk türü idarenin hizmet kusuru yani kusur sorumluluğudur. Hizmetin kötü işlemesi, geç işlemesi veya hiç işlememesinde yapay zekâdan kaynaklı bir kusur söz konusu ise kural olarak idare bizatihi sorumlu olacaktır ve tazminat sorumluluğunu yapay zekâ üreticisine/tasarımcısına rücu edecektir. Ancak idare, yapay zekâdan kaynaklı zararlardan hiçbir şekilde sorumlu olamayacağını yapay zekâ teknolojisine dayandırırsa, burada tüm sorumluluğun üretici veya tasarımcıda kalabileceği söylenebilecek midir? Zira farklı açılardan yaklaşıldığında idare de bu yönde bir argüman ileri sürmede yeterli dayanaklara sahiptir. Asıl sorumluluk yapay zekâyı üreten şirkette midir yoksa idarede midir? Şirket, kamu hizmeti alıcısının zarar talebinde üçüncü kişi konumundadır, dolayısıyla zararın tazmini talebi idareye değil de üretici şirkete yöneltilebilecek midir? Bu açıdan zarar görenin, idare yanında yapay zekâ üreticisinin/tasarımcısının sorumluluğuna gitmesinin de önü açılacaktır. Diğer yandan, üreticinin kusuru var ise yapay zekânın işlemi/eylemi “üçüncü kişinin davranışı” kalıbına sokulabilir mi? Cevap olumlu ise idarenin sorumluluğu bu doğrultuda azalabilir veya ortadan kalkabilir.

Tabi burada yapay zekâ türleri açısından farklı bir yorum gerekecektir. Zira, her yapay zekâ türünde kusurun tespiti değişmektedir ki otonom yapay zekâlarda bu tespit güçleşebilecektir. Örneğin idarenin ulaşım hizmetinde kullanılan otobüsü idare eden

94 ALEXANDRE, 2017, s. 32. 
yapay zekâ donanımlı bir robotun, kaza anında verdiği karar illiyet bağını kesecektir. Bu durumda ortaya çıkan zararda, doğrudan yapay zekâ üreticisinin/tasarlayıcısının veya kullanıcısının sorumluluğuna gidilebilecek midir? Düzensiz zemin yüzeyleri, beklenmedik engeller, küçük çocuklar ve bir dizi başka faktör, robotun güvenli bir şekilde kontrol edilmesini zorlaştırabilecektir ${ }^{95}$. Konuyla ilgili olasılıklar, yapay zekânın gelişimine ve hukuki kişiliğinin tanınmasına göre farklı yanıtlar da ortaya çıkaracaktır. Mevcut durumda, hukuk düzeninin yapay zekâyı kişi olarak tanımaması sebebiyle, idarenin mali sorumluluğu çerçevesinde yapay zekâdan kaynaklı zararların tazmin yükümlülüğünün idarede olacağı belirtilmelidir.

Öte yandan, yapay zekânın hukuki kişiliğinin tanınmaması ve kusur ispatının güçlüğü açısından, idarenin kusur sorumluluğu yerine kusursuz sorumluluğundan bahsedilmesi de önerilebilir"96. Bu şekilde yapay zekâ kullanımı "risk ilkesi” çerçevesinde değerlendirilerek idarenin sorumluluğuna gidilebilecektir. Bugün için yapay zekânın idare hukukunda, patlayıcı maddeler, ateşli silahlar, riskli taşıtlar, tehlikeli yöntemler gibi aşırı tehlike yaratan ve idarenin kestiremeyeceği, önleyemeyeceği olumsuz sonuçlar doğuran bir araç/faaliyet olarak kabul edilmesi mümkün olabilir. Elbette burada illiyet bağının kurulması da önem taşıyacaktır. Üçüncü kişinin davranışı hizmet kusurunda söz konusu olduğundan, burada yapay zekâya ilişkin üretici/tasarımcıdan kaynaklı bir kusur dahi olsa idare sorumlu tutulacaktır. Kanımızca en isabetli çözüm güncel durumda bu şekilde oluşturulabilir. Bununla birlikte yapay zekâdaki gelişime paralel olarak, belki de daha farklı bir kategori yaratılarak sosyal risk ilkesinde olduğu gibi illiyet bağının varlığ 1 aranmayan bir sorumluluk türü de geliştirilebilecektir. Ancak tekrar belirttiğimiz üzere, yapay zekânın öz farkındalık kazanan bir türü için bu önerilerin yeniden gözden geçirilmesi gerekecektir. Zaten bu nedenle yapay zekânın hukuki kişiliğinin kabul edilip edilmeyeceği ve hukuki statüsünün belirlenmesi önem taşımaktadır.

95 RICHARDS/SMART, 2013, s. 13.

96 Konuyu medeni hukuk boyutuyla ele alan Ercan; kusur sorumluluğunun, robotik alanında somut olaya uygulanabilirliği noktasında de lege feranda tatmin edici çözümler sunmayacağını belirterek; her bir türe, özelliklerine ve kullanım alanlarına uygun bir kusursuz sorumluluk türünün öngörülmesi yönünde görüş sunmuştur, ERCAN, Cannur, "Robotların Fiillerinden Doğan Hukuki Sorumluluk Sözleşme Diş1 Sorumluluk Hallerinde Çözüm Önerileri”, Türkiye Adalet Akademisi Dergisi, Y1l: 11, Sayı: 40, 2019 , s. 49. 
Yukarıda değindiğimiz Robotikler Hakkında Medenî Hukuk Kuralları Tavsiye Raporu, sorumluluk alanındaki yaklaşımıyla dikkat çekicidir. Raporda, bir robotun otonom kararlar alabildiği senaryoda, robotun neden olduğu zararlar için geleneksel kuralların yasal sorumlulukların doğumuna yeterli olmayacağı öngörülmüştür. (m. $\mathrm{Z} / \mathrm{AF})^{97}$. Yeni nesil robotların (the new generation of robots $)^{98}$ kendi değişken deneyimlerinden otonom bir şekilde öğreneceği, çevreleriyle benzersiz ve öngörülemeyen bir şekilde etkileşime gireceği belirtilerek, davranışlarındaki öngörülemezliğin mevcut hukuki düzenlemenin yeni nesil robotların neden olduğu hasarı karşılamak için yeterli olmayacağı ifade edilmiştir. (m. Z/AI). Raporda, en azından mevcut aşamada sorumluluğun robota değil insana ait olduğu belirtilirken, sorumluluğu üstlenen taraflar belirlendikten sonra otonom robotlar için verilen eğitim seviyesi, öğrenme kapasitesi, özerklik yeteneği ile orantılı olarak, sorumluluğun kapsamının belirlenmesine işaret edilmiştir (m. 56) ${ }^{99}$.

Raporun, yapay zekâ hakkındaki hukuki belirsizlikleri nihai olarak çözmediğini ve sunduğu tavsiyelerle yapılacak çalışmalara bir rehber oluşturduğunu vurgulamak gerekir. Bu kapsamda rapor, uzun vadede robotlar için bir hukuki statü oluşturulmasını tavsiye ettiği gibi elektronik kişilik ismiyle yeni bir statü önerisi getirmektedir. Dolayısıyla raporun ilerleyen zamanda yapay zekânın bir kişiliğinin olması gerektiği yönünde bir anlayışa sahip olduğunu çıkarabiliyoruz. Elektronik kişilik statüsü önerisi ile en azından

97 Ayrıca mevcut hukuki düzenleme kapsamında robotların, üçüncü şahıslara zarar veren eylemler veya ihmallerden tek başına sorumlu tutulamayacağı; sorumluluğa ilişkin mevcut kuralların, robotun eylemi veya ihmalinin nedeninin imalatçı, operatör, mal sahibi veya kullanıcı gibi belirli bir insan temsilcisine kadar takip edilebildiği ki bu temsilcinin robotun zararlı davranışını önceden görebileceği ve önleyebileceği; buna ek olarak, üreticiler, operatörler, sahipler veya kullanıcılar bir robotun eylemleri veya ihmallerinden kesinlikle sorumlu tutulabileceği belirtilmiştir (m. Z/AD)

98 Raporda bir tanım verilmemekle birlikte madde düzenlemesinden, yeni nesil robotlar, yapay zekâ donanımlı robotlar olarak değerlendirilebilecektir. Rapor genel olarak yapay zekâ ve robot terimleri için sınırlayıcı olmayan esnek bir yaklaşım benimsemiştir.

99 Anılan raporda sorumlulukla ilgili olarak, mevcut düzlemde zarar ile yapay zekâ arasında nedensellik ilişkisi bulunup bulunmadığına bakılması gerektiği; tazminat türleri ve biçimlerinin sınırlandırılmaması gerektiği hususları ifade edilmiştir. Komisyon genel olarak, belirli robot kategorileri için zorunlu bir sigorta planı oluşturulması; üreticinin, programcının, mal sahibinin veya kullanıcının bir tazminat fonuna katkıda bulunmaları halinde sınırlı sorumluluktan yararlanmalarına ve ayrıca bir robotun neden olduğu hasar durumunda tazminatı garanti etmek için müş̧ereken sigorta yaptırmalarına izin verilmesi; bir robot ile fonu arasındaki bağlantının, belirli bir sicilde yer alan bireysel bir kayıt numarasıyla görünür hale getirilmesinin sağlanması gibi öneriler sunmuştur. 
en karmaşık otonom robotların, neden olabilecekleri zarardan sorumlu olması, robotların otonom kararlar verdiği veya üçüncü şahıslarla bağımsız olarak etkileşime girdiği durumlarda elektronik kişiliğin uygulanabilmesi tavsiye edilmiştir. (m. 59/f). Elektronik kişilik kabul edildiğinde zararın nasıl tazmin edileceği konusunda raporda özel bir öneri bulunmamakla birlikte, oluşturulacak bir tazminat bir fonu ile sigorta ve bir ödeme sistemi kurulması ilk planda düşünülebilir ${ }^{100}$. Öte yandan otonom robotlar açısından, ihmalkâr davranan kişiye değil, belirli koşullar altında riskleri en aza indirebilecek ve olumsuz etkilerle başa çıkabilecek kişiye odaklanılması gerektiği belirtildiğinden, raporda kendine özgü bir kusursuz sorumluluk halinin kabul edildiği görülmektedir ${ }^{101}$. Bir bütün olarak değerlendirildiğinde raporun, elektronik kişiliğin kabul edilmesi halinde sorumluluğun da yapay zekâda olmasına yönelik açık kapı bıraktığını düşünüyoruz. Zira yukarıda da ifade edildiği gibi rapor, mevcut durumda da yapay zekâya verilen talimatların ve özerkliğin derecesi ile gerçek ve tüzel kişilerin sorumluluğun değişebileceğini söylemiştir.

Diğer taraftan bir düzenleme taslağına yer verilen Avrupa Parlamentosu'nun 20 Ekim 2020 tarihli "Yapay Zekâ İçin Hukuki Sorumluluk Rejimi”ne ilişkin kararında102, yapay zekâ sistemlerine hukuki kişilik vermenin gerekli olmadığı ifade edilmiştir (m. 7). Kararda yapay zekâ kaynaklı hasarların; neredeyse her zaman, sistemleri inşa eden, dağıtan veya sistemlere müdahale edenlerin etkileri sonucunda oluştuğu belirtilmiştir. Devamında, yapay zekâ sistemlerinin opaklığının, bağlantısının ve özerkliğinin, yapay zekânın zararlı eylemlerinin geriye doğru izlenmesini pratikte çok zor, hatta imkânsız hale getirebileceği görüşü de verilmiştir. Bununla birlikte kararda söz konusu engelin,

${ }^{100} \mathrm{Bu}$ konuda Akdağ, otonom yapay zekâlara hukuki kişilik tanınması görüşüyle, sorumluluğun yapay zekâya yüklendiği hallerde Trafik Garanti Sigorta Fonu'na benzer ortak bir fon oluşturulmasını önermiştir. Bu şekilde, üreticinin, kullanıcının hatta devletin bu fona katkı sağlaması gerektiğini; fonun devamlılığına katkı sağlamak bakımından, ticari faaliyetlerde bulunan yapay zekâların gerçekleştirdikleri ticari faaliyetler neticesinde elde edilen kazançların bir kısmının bu fona aktarılmasının, öngörülemez yapay zekâ fiilleri neticesinde riskin tek tarafa yükletildiği alternatif çözüm önerilerinden daha adil olduğunu belirtmiştir, AKDAĞ, 2019, s. 18-19. Konuyla ilgili diğer değerlendirme için bkz. ALEXANDRE, 2017, s. 30-32.

${ }^{101}$ Benzer yönde görüş için bkz. KILIÇARSLAN, 2019, s. 381.

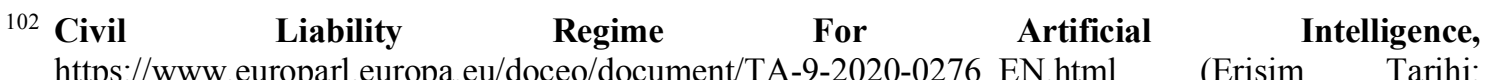
15.05.2021). 
yaygın olarak kabul edilen sorumluluk kavramlarına uygun olarak, yapay zekâ sistemiyle ilişkili riski yaratan, sürdüren veya kontrol eden tüm değer zincirindeki farklı kişilerin sorumlu kılınmasıyla aşılabileceği açıklanmıştır. Öte yandan, yapay zekâdan kaynaklı farklı risklerin olduğunu, yüksek risk barındıran ve otonom olarak hareket eden bir yapay zekâ sistemi için ortak bir katı sorumluluk rejimi oluşturmanın makul göründüğü ifade edilmiştir (m. 14).

Belirtmek gerekir ki bilimsel gelişmeler çoğaldıkça, yapay zekânın sebep olduğu zararlar karşısında klasik sorumluluk kurallarının yeterli olmayacağı ifade edilebilir. Yapay zekâ için uygun sorumluluk rejimi hakkında, yaygın rejimlerin hiçbirinin yapay zekâ tabanlı robotların zorluklarına tam olarak uymadığı ifade edilmektedir ${ }^{103}$. Çünkü otonom makineler, onları diğer (normal) makinelerden ayıran özelliklere sahiptir, örneğin derin öğrenme (deep learning) ile insan müdahalesi olmadan deneyim kazanma yeteneğine sahip olma gibi. Bu özellikler aynı zamanda sorumluluğun belirlenmesi için sorunlar da yaratmaktadır ${ }^{104}$. İdare hukuku alanında da idarenin sorumluluğu bakımından yapay zekânın yol açacağı farklı bir yaklaşım söz konusu olacaktır. Bu anlamda yapay zekâya ilişkin hukuki düzenlemelerin esnek hukuk (soft law) yoluyla oluşturulmasına dair öneriler, yapay zekâ ve idarenin sorumluluğu meselesinde faydalı bir yaklaşım olarak görünmektedir Yapay zekâya dair bilimsel gelişmeler aralıksız devam ettiği için, oluşturulan hukuk kuralları değişikliğe açık olacaktır. Yapay zekâ ve sorumluluk meselesinde açık olan husus, manzaranın katıksız karmaşıklığıdır. Esnek hukuk da bu karmaşıklığı açmada anahtar rolü üstlenebilir. İdare hukuku içtihadi karakteri olan bir hukuk dalıdır. $\mathrm{Bu}$ itibarla, içtihadi karakterinin verdiği avantajla idare hukuku, uyuşmazlıkların çözümünde kullandığı kavram ve ilkelerin üstüne yenilerini ekleyebilecek veya içeriklerini genişletebilecektir.

103 RACHUM-TWAIG, Omri, "Whose Robot Is It Anyway?: Liability for Artificial-Intelligence-Based Robots", University of Illinois Law Review, Volume: 2020, Issue: 4, 2020, s. 1174, https://illinoislawreview.org/wp-content/uploads/2020/08/Rachum-Twaig.pdf (Erişim Tarihi: 13.11.2020).

104 Ayrıntılı bilgi için bkz. OPITZ, Paul, Civil Liability and Autonomous Robotic Machines: Approaches in the EU and US, TTLF Working Papers No. 43, Stanford-Vienna Transatlantic Technology Law Forum, 2019, s. 5 vd. https://law.stanford.edu/wpcontent/uploads/2019/02/opitz wp43.pdf (Erişim Tarihi: 13.11.2020). 


\section{SONUC}

Toplumun yapay zekâ alanında hukuki düzenlemelere ihtiyacı var mıdır? Hukukun yapay zekâ alanında uzmanlaşması gerekli midir? Yapay zekâya hukuki kişilik verilmesinin faydası nedir? Yapay zekâ için sorumluluk nasıl inşa edilmelidir? Aslında soru ne kadar basit ise cevap o kadar karmaşıktır. Bunun gibi birçok soru hukuk yapıcılarının ajandasına çoktan girmiş bulunmaktadır. Bu sorular aynı zamanda yolu yapay zekâ ile kesişen herkesin gündemini ilgilendirecek sorulardır. Zira fark edilsin ya da edilmesin, sürekli artan görevleri ile yapay zekâlar gündelik hayatımızda yerini almıştır. Bugün için yapay zekânın sonuçları henüz tam olarak ölçülebilir değildir. Bununla birlikte, olgunlaşan bir yapay zekânın üretebileceği köklü değişiklikler karşısında hukukun kendi müdahale alanını bugünden ele almaya başlaması gerekecektir.

$\mathrm{Bu}$ anlamda hukukun bir Collingridge ikilemi içinde bulunduğu belirtilecektir. "Bilgi Toplumu"ndan "Algoritmik Toplum"a giderken teknolojinin temposuna uymaya çalışan hukukun sahip olduğu kuralların, yapay zekânın karmaşıklıklarını ve zorluklarını ele almaya uygun olmadığı ortadadır. Örneğin özerk yapay zekânın ve belki de silahla donatılmış olanların, kolluk tarafindan kullanılması durumunda yaşanacak hukuki tartışmalar şimdiden tahmin edilebilir. Ancak yapay zekâ teknolojisindeki gelişmelerin hukuk sistemi üzerindeki uzun vadeli etkileri şimdiden tahmin edilebilir değildir. Bu doğrultuda ortaya çıkarılan çeşitli metinler ve raporlardan gözlemlendiği üzere, hukukun şu anda "bekle ve gör" yaklaşımı içinde olduğunu ve esnek hukuk enstrümanları ile bu sürece hazırlandığı belirtilebilir. Güncel durumda hukukun yapay zekâya ilişkin çözmeye çabaladığı iki konu önceliklidir: Hukuki kişiliğe bağlı olarak hukuki statü ve sorumluluk.

Yapay zekâya hukuki bir kişilik tanınması ve hukuki statüsünün belirlenmesi konularında modern hukuk bir formül bulma çabası içindedir. Çünkü yapay zekâ sistemlerindeki ve algoritma teknolojisindeki ilerlemeler er ya da geç bu hukuki belirlemeleri zorunlu kılacak gibi görünüyor. Bu doğrultuda hukuk, yapay olan ile doğal olanın yollarının kesişmesi durumuna sessiz kalmayarak, bu ilişkiyi dengeleyen bir yol çizme arzusu içinde olacaktır. Aslında yapay zekâ ile ilgili hukuktaki belirsizlikler, hukuki kişilik konusunun henüz netleştirilememesinden kaynaklanmaktadır. Mevcut gelişim seviyeleri açısından şu an için önemli açmazlar yaratmasa da gelecekte meydana 
gelebilecek teknolojik sıçramaların ciddi sonuçlar doğurabileceği kabul edilmelidir. Yapay zekânın hukuki kişiliğine ve statüsüne yönelik getirilen önerilerin geliştirilmeye açık olduğu ve bu konuda birçok belirsizliğin bulunduğu ifade edilebilir. Ancak yapay zekâ alanında doğacak hukuki sorunları, yapay zekâyı eşya ya da köle olarak kabul ederek çözemeyeceğimiz düşüncesindeyiz. Bu açıdan türleri içindeki farklılıklar da gözetilerek, tüzel kişilik veya elektronik kişilik önerilerinin diğer görüşlere nazaran ayaklarının daha sağlam bastığı kanaatindeyiz. Nitekim günümüz hukuk sisteminde, hukuki kişiliğin insanlıkla özdeş olduğu, yani homo sapiensin genetik materyaline sahip olmanın hukuki kişilik için gerekli bir koşul olmadığı kabul edilmiştir.

Yapay zekâ, diğer hukuk dalları kadar idare hukukunu da etkileyecek bir teknolojidir ve idare hukuku yapay zekânın getirdiği zorlukların üstesinden gelme çabası içinde olacaktır. İdare hukuku açısından, yapay zekâ teknolojisinin düzenlenmesi ve denetlenmesinde idarenin yeni görev ve yetkilere sahip olacağı belirtilmelidir. $\mathrm{Bu}$ alandaki ikincil mevzuatın oluşturulmasında idarenin, kendi içinde uzmanlaşma yoluna gitmesi kaçınılmaz olacaktır. Böylece, organik ve fonksiyonel anlamda idare kavramlarının yapay zekâ konularıyla genişleyeceği belirtilebilir. Yapay zekâ teknolojisinin düzenlenmesi ve denetlenmesi faaliyeti yanında idarenin kendisi de bizatihi yapay zekâ sistemlerinden faydalanabilecektir. Pek çok kamu hizmetinin yürütülmesinde idarenin yapay zekâ istihdamına gidebileceği, idari kavramların ve kurumların değişime uğrayacağı öngörülebilir; kamu hizmetinin dijitalleşmesi, dijital vatandaşlık, dijital idari usul, otonom idari işlem, vs. Yine bu faaliyetler neticesinde idarenin kendi içinde uzmanlaşan birimleri oluşturulacaktır. Nitekim ülkemizde yürütme organına bağlı birimler yapay zekâ alanında çeşitli görevlere sahip idareler olarak karşımıza çıkmaktadır.

Ülkemizde idare hukukuna yönelik eleştirilerin ve önerilerin bütünleştiğgi idari usul yasasının eksikliği, belki de idarenin yapay zekâ ile buluşması ile çözülebilecektir. İdare hukukumuzda beklenen "gün 1şığı yasa"ları, yapay zekâ ve algoritma teknolojisinin mevzuatının oluşturulmasıyla birlikte tekrar gündeme gelecektir. Çünkü yapay zekâ alanındaki faaliyetlerin şeffaf ve denetlenebilir olmasının gerekliliği, bu alandaki metinlerde kabul edilen temel kurallardan biridir. 
Yapay zekânın sorumluluğu konusunda idare hukuku açısından idarenin sorumluluğuna dair yerleşik kuralların yeniden ele alınması gerekecektir. Mevcut sistemde, yapay zekâdan kaynaklı ve idarenin taraf olduğu bir zararda, yapay zekânın doğası gereği karşılaşılacak ispat güçlüğü açısından, idarenin kusursuz sorumluluğunun kabul edilmesinin daha uygun olacağı ve bu sorumluluğun da risk ilkesi çerçevesinde değerlendirilmesi gerektiği düşüncesindeyiz. Öte yandan, yapay zekâ teknolojisindeki ilerlemeler bugün olduğundan daha farklı bir yorumu gerektirecektir. Yapay zekâ konularının düzenlenmesinde, yapay zekânın türleri, özerklik derecesi, işlevi, çevreyle ve insanla etkileşimi gibi birçok unsurun göz önünde tutulması gerekmektedir. Dolayısıyla idarenin sorumluluğunun yapay zekâ bakımından farklılaşacağı, belki de illiyet bağı aranmayan sosyal risk ilkesi gibi farklı bir kategori de oluşturulabileceği öngörüsündeyiz. İçtihadi karakterinin verdiği avantajla, yapay zekâ ve idarenin sorumluluğu konusunda idare hukukunda somut ve ilkesel çözümler geliştirilebileceğini belirtmek isteriz.

\section{KAYNAKÇA}

\section{Kitaplar, Makaleler ve Çalıșma Raporları}

AKDAĞ, Şükrü Yakup, "Yapay Zekanın Sorumluluğu Üzerine Düşünceler”, Sorumluluk Hukuku Seminerler 2018, Ed. BAYSAL, Başak, İstanbul, On İki Levha Yayıncılık, 2019.

AKKURT, Sinan Sami, "Yapay Zekânın Otonom Davranışlarından Kaynaklanan Hukukî Sorumluluk”, Uyuşmazlık Mahkemesi Dergisi, Sayı: 13, 2019.

ALEXANDRE, Filipe Maia, The Legal Status of Artificially Intelligent Robots: Personhood, Taxation and Control, 2017, http://dx.doi.org/10.2139/ssrn.2985466 (Erişim Tarihi: 12.11.2020).

ARF, Cahit, “Makine Düşünebilir mi ve Nasıl Düşünebilir?”, Atatürk Üniversitesi 1958-1959 Öğretim Yılı Halk Konferansları, Atatürk Üniversitesi - Üniversite Çalışmalarını Muhite Yayma ve Halk Eğitimi Yayınları Konferanslar Serisi No: 1, Erzurum, 1959.

BASSINI, Marco/GREGORIO, Giovanni De/MACCHIA, Marco vd., The Ethics and Law of AI, La Fondazione Leonardo - Civiltà delle Macchine, yy., https://fondazioneleonardo- 


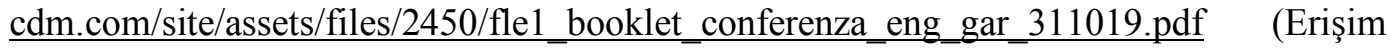
Tarihi: 12.11.2020).

BAYAMLIOĞLU, Emre, “Akıllı Yazılımlar ve Hukuki Statüsü: Yapay Zeka ve Kişilik Üzerine Bir Deneme", Uğur Alacakaptan'a Armağan, Cilt II, İstanbul Bilgi Üniversitesi Yayınları, İstanbul, 2008.

BIZONY, Piers, "Focus: \#1 The First Law: A Robot May Not Injure a Human Being, or, through Inaction, Allow a Human being to Come to Harm”, Engineering \& Technology, Volume: 10, No. 6, 2015, http://dx.doi.org/10.1049/et.2015.0621 (Erişim Tarihi: 12.11.2020).

BOZKURT YÜKSEL, Armağan Ebru /BAK, Başak, "Yapay Zeka", Futurist Hukuk, Aristo Yayınevi, İstanbul, 2018.

BUCHANAN, Bruce G., "A (Very) Brief History of Artificial Intelligence”, AI Magazine, Volume: 26, No. 4, 2005, https://doi.org/10.1609/aimag.v26i4.1848 (Erişim Tarihi: 12.11.2020).

BUOSO, Elena, "Fully Automated Administrative Acts in the German Legal System", European Review of Digital Administration \& Law-Erdal, Volume: 1, Issue: 1-2, 2020.

CALO, Ryan, "Robotics and the Lessons of Cyberlaw”, California Law Review, Volume: 103, No. 3, 2015, http://dx.doi.org/10.2139/ssrn.2402972 (Erişim Tarihi: 12.11.2020).

CHOPRA, Samir/WHITE, Laurance, "Artificial Agents: Personhood in Law and Philosophy", Proceedings of the 16th Eureopean Conference on Artificial Intelligence, ECAI'2004, 2004, http://www.sci.brooklyn.cuny.edu/ schopra/agentlawsub.pdf (Erişim Tarihi: 12.11.2020).

COSTANTINO, Fulvio, "Public Officials and the Design of Algorithms Lessons. from the Italian Experience", European Review of Digital Administration \& Law-Erdal, Volume: 1, Issue: 1-2, 2020.

ČERKA, Paulius/GRIGIENĖ, Jurgita/SIRBIKYTĖ, Gintare,, "Is it possible to grant legal personality to artificial intelligence software systems?", Computer Law \& Security Review, Volume: 33, Issue: 5, 2017, https://doi.org/10.1016/j.clsr.2017.03.022 (Erişim Tarihi: 12.11.2020). 
DURAL, Mustafa/ÖĞÜZ Tufan, Türk Özel Hukuku, Kişiler Hukuku, Cilt II, 18. Basım, Filiz Kitabevi, İstanbul, 2017.

DURAN, Lütfi, İdare Hukuku Ders Notları, Fakülteler Matbaası, İstanbul, 1982.

EASTERBROOK, Frank H., "Cyberspace and the Law of the Horse", University of Chicago Legal Forum,

1996 https://chicagounbound.uchicago.edu/cgi/viewcontent.cgi?article $=2147 \&$ context=journal articles (Erişim Tarihi: 12.11.2020).

ERCAN, Cannur, "Robotların Fiillerinden Doğan Hukuki Sorumluluk Sözleşme Dışı Sorumluluk Hallerinde Çözüm Önerileri”, Türkiye Adalet Akademisi Dergisi, Y1l: 11, Sayı: 40, 2019.

ERDÉLYI, Olivia J./GOLDSMITH, Judy, "Regulating Artificial Intelligence Proposal for a Global Solution", AIES '18: Proceedings of the 2018 AAAI/ACM Conference on AI, Ethics, and Society, 2018, https://dl.acm.org/doi/10.1145/3278721.3278731 (Erişim Tarihi: 12.11.2020).

ERSOY, Çağlar, Robotlar, Yapay Zekâ ve Hukuk, İstanbul, On İki Levha Yayınc1lık, 2019.

GASPARETTO, Alessandro, "Robots in History: Legends and Prototypes from Ancient Times to the Industrial Revolution", Explorations in the History of Machines and Mechanisms, History of Mechanism and Machine Science, Ed. LÓPEZ-CAJÚN, Carlos/CECCARELLI, Marco, Volume: 32, 2016, https://doi.org/10.1007/978-3-31931184-5 5 (Erişim Tarihi: 12.11.2020).

GEDIK, Gülşen, "Robotlara Karşı Gerçek Kişilerin Korunması Açısından Robot Vergisi Önerisi”, Marmara Üniversitesi Hukuk Fakültesi Hukuk Araştırmaları Dergisi, Cilt: 26, Sayı: 1, Haziran 2020.

GÖZLER, Kemal, İdare Hukuku, Cilt I, 3. Basım, Ekin Yayınevi, Bursa, 2019.

GUIHOT, Michael/Matthew, Anne F./Suzor, Nicolas, "Nudging Robots: Innovative Solutions to Regulate Artificial Intelligence”, Vanderbilt Journal of Entertainment \& Technology Law, Forthcoming, Volume: 20, Issue: 2, 2017, https://ssrn.com/abstract=3017004 (Erişim Tarihi: 12.11.2020). 
HAGEMANN, Ryan/SKEES, Jennifer/THIERER, Adam D., "Soft Law for Hard Problems: The Governance of Emerging Technologies in an Uncertain Future", Colorado Technology Law Journal, Volume: 17, No. 1, 2018, https://ctlj.colorado.edu/wpcontent/uploads/2019/03/3-Thierer_3.18.19.pdf (Erişim Tarihi: 12.11.2020).

HARARI, Yuval Noah, Homo Deus: Yarının Kısa Bir Tarihi, Çev. TANELİ, Poyzan Nur, Kolektif Kitap, İstanbul, 2016.

HINTZE, Arend, "Understanding The Four Types Of AI, From Reactive Robots To Self-Aware Beings", The Conversation, 14.11.2016, https://theconversation.com/understanding-thefour-types-of-ai-from-reactive-robots-to-self- aware-beings-67616 (Erişim Tarihi: 12.11.2020).

HOBBES, Thomas, Leviathan ("Hobbes's Leviathan reprinted from the edition of 1651), Clarendon Press, Oxford, 1909, http://files.libertyfund.org/files/869/0161 Bk.pdf (Erişim Tarihi: 21.05.2021).

İMRE, Zahit, Medeni Hukuka Giriş, 3. Basım, Fakülteler Matbaası, İstanbul, 1980.

KILIÇARSLAN, Seda Kara, "Yapay Zekanın Hukuki Statüsü ve Hukuki Kişiliği Üzerine Tartışmalar", Ylıırım Beyazıt Hukuk Dergisi, Sayı: 2, Yı1: 4, 2019, https://doi.org/10.33432/ybuhukuk.599224 (Erişim Tarihi: 12.11.2020).

KURZWEIL, Ray, "The Law of Accelerating Returns", Alan Turing: Life and Legacy of a Great Thinker, Ed. Christof Teuscher, Springer, Heidelberg, 2004, https://doi.org/10.1007/978-3-662-05642-4_16 (Erişim Tarihi: 16.11.2020).

LEHMAN-WILZIG, Sam, "Frankenstein Unbound: Towards A Legal Definition Of Artificial Intelligence", Futures, Volume: 13, Issue: 6, 1981, https://doi.org/10.1016/00163287(81)90100-2 (Erişim Tarihi: 12.11.2020).

LESSIG, Lawrence, "The Law of the Horse: What Cyberlaw Might Teach", Harvard Law Review, Volume: 113, No. 2, 1999, https://www.jstor.org/stable/1342331 (Erişim Tarihi: 12.11.2020).

MCCARTHY, John, What is Artificial Intelligence?, 2007, http://wwwformal.stanford.edu/jmc/whatisai.pdf (Erişim Tarihi: 12.11.2020). 
MCCARTHY, John/MINSKY Marvin L./ROCHESTER Nathaniel/CLAUDE E. Shannon, A Proposal for Dartmouth Summer Research Project on Artificial Intelligence, 1955, http://jmc.stanford.edu/articles/dartmouth/dartmouth.pdf (Erişim Tarihi: 12.11.2020).

MEHR, Hila, Artificial Intelligence for Citizen Services and Government, 2017, https://ash.harvard.edu/files/ash/files/artificial_intelligence_for_citizen_services.pdf (Erişim Tarihi: 12.11.2020).

NEFF, Gina/NAGY, Peter, "Talking to Bots: Symbiotic Agency and the Case of Tay", International Journal of Communication, Volume: 10, 2016, https://ijoc.org/index.php/ijoc/article/view/6277 (Erişim Tarihi: 12.11.2020).

NILSSON, Nils J., The Quest for Artificial Intelligence: A History of Ideas and Achievements, Cambridge, UK, Cambridge University Press, 2010, https://ai.stanford.edu/ nilsson/QAI/qai.pdf (Erişim Tarihi: 12.11.2020).

OPITZ, Paul, Civil Liability and Autonomous Robotic Machines: Approaches in the EU and US, TTLF Working Papers No. 43, Stanford-Vienna Transatlantic Technology Law Forum, 2019, https://law.stanford.edu/wp-content/uploads/2019/02/opitz_wp43.pdf (Erişim Tarihi: 13.11.2020).

ÖZAY, İl Han, Günışı̆̆ında Yönetim, Filiz Kitabevi, İstanbul, 2004.

ÖZSUNAY, Ergun, Medeni Hukukumuzda Tüzel Kişiler: Tüzel Kişilerin Genel Teorisi, Dernekler, Vakıflar (Tüzel Kişiler), 5. Basım, Sulhi Garan Matbaası, İstanbul, 1982.

PALIWALA, Abdul, "Rediscovering Artificial Intelligence and Law: An Inadequate Jurisprudence?", International Review of Law, Computers \& Technology, Volume: 30, Issue: 3, 2016, http://dx.doi.org/10.1080/13600869.2016.1229651 (Erişim Tarihi: 12.11.2020).

PÉRENNOU, Thommas, "State of the Art on Legal Issues", Ethicaa Project, Ethics and Autonomus Agents, Ağustos 2014, https://ethicaa.greyc.fr/media/files/ethicaa.delivrable.1.pdf (Erişim Tarihi: 12.11.2020).

PRICE, Monroe E./VERHULST, Stefaan G., Self-Regulation and the Internet, Kluwer Law International, Hollanda, 2005. 
RACHUM-TWAIG, Omri, "Whose Robot Is It Anyway?: Liability for Artificial-IntelligenceBased Robots", University of Illinois Law Review, Volume: 2020, Issue: 4, 2020, https://illinoislawreview.org/wp-content/uploads/2020/08/Rachum-Twaig.pdf (Erişim Tarihi: 13.11.2020).

REDDY, Trips, "Why it matters that AI is better than humans at games like Jeopardy", 27.06.2017, https://www.ibm.com/blogs/watson/2017/06/why-it-matters-that-ai-is-betterthan-humans-at-their-own-games/ (Erişim Tarihi: 12.11.2020).

RICHARDS, Neil M./SMART, William D., How Should the Law Think About Robots?, 2013, http://ssrn.com/abstract=2263363 (Erişim Tarihi: 12.11.2020).

SCHERER, Matthew U., "Regulating Artificial Intelligence Systems: Risks, Challenges, Competencies, and Strategies", Harvard Journal of Law \& Technology, Volume: 29, No. 2, 2015, http://jolt.law.harvard.edu/articles/pdf/v29/29HarvJLTech353.pdf (Erişim Tarihi: 12.11.2020).

SILVER, David/SCHRITTWIESER Julian/SIMONYAN Karen vd., "Mastering the Game of Go without Human Knowledge", Nature, Volume: 550, Issue: 7676, 2017, https://doi.org/10.1038/nature24270 (Erişim Tarihi: 12.11.2020).

SOLUM, Lawrence B., "Legal Personhood for Artificial Intelligences", North Carolina Law $\begin{array}{llll}\text { Review, } & \text { Volume: } 70, & \text { No. } & 4,\end{array}$ https://scholarship.law.unc.edu/cgi/viewcontent.cgi?article=3447\&context=nclr $\quad$ (Erişim Tarihi: 12.11.2020).

STANILA, Laura, "Living in the Future: New Actors in the Field of Criminal Law - Artificial Intelligence", Legal Science: Functions, Significance and Future in Legal Systems II, Conference: The 7th International Scientific Conference of the Faculty of Law of the University of Latvia, 2019, https://doi.org/10.22364/iscflul.7.2.24 (Erişim Tarihi: 13.11.2020).

STONE, Christopher D., "Should Trees Have Standing? Toward Legal Rights for Natural Objects", Southern California Law Review, Volume: 45, 1972, https://iseethics.files.wordpress.com/2013/02/stone-christopher-d-should-trees-havestanding.pdf (Erişim Tarihi: 12.11.2020). 
STONE, Peter/BROOKS, Rodney/BRYNJOLFSSON Erik vd., "Artificial Intelligence and Life in 2030", One Hundred Year Study on Artificial Intelligence: Report of the 2015-2016 Study Panel, Stanford University, Stanford, CA, 2016, https://ai100.stanford.edu/sites/g/files/sbiybj9861/f/ai_100_report_0831fnl.pdf_Erişim Tarihi: 12.11.2020).

TAMER, Halil Yasin/ÖVGÜN Barış, "Yapay Zeka Bağlamında Dijital Dönüşüm Ofis”, Ankara Üniversitesi Siyasal Bilgiler Fakültesi Dergisi, Cilt: 75, Sayı: 2, 2020.

TEKİNAY, Selâhattin Sulhi, Medenî Hukukun Genel Esasları ve Gerçek Kişiler Hukuku, 6. Basım, Filiz Kitabevi, İstanbul, 1992.

TURGUT, Nükhet, “İhtiyat İlkesi”, Ankara Üniversitesi Hukuk Fakültesi Dergisi, Cilt: 45, Say1: 1-4, 1996.

TURING, Alan M., “Computing Machinery and Intelligence”, Mind, Volume: 59, No. 236, 1950, http://www.jstor.org/stable/2251299 (Erişim Tarihi: 12.11.2020).

TURING, Alan M., "On Computable Numbers, with an Application to the Entscheidungsproblem", Proceedings of Turing the London Mathematical Society, Series $2, \quad$ Volume: $42, \quad$ Issue: 1937, https://www.cs.virginia.edu/ robins/Turing_Paper_1936.pdf (Erişim Tarihi: 12.11.2020).

WENG, Yueh-Hsuan/CHEN, Chien-Hsun/SUN, Chuen-Tsai, "The Legal Crisis of Next Generation Robots: On Safety Intelligence", ICAIL '07: Proceedings of the 11th International Conference on Artificial Intelligence and Law, 2007, https://doi.org/10.1145/1276318.1276358 (Erişim Tarihi: 12.11.2020).

WILLICK, Marshal S., “Artificial Intelligence: Some Legal Approaches and Implications,”, Al Magazine, Volume: 4, No. 2, 1983, https://doi.org/10.1609/aimag.v4i2.392 (Erişim Tarihi: 12.11.2020). 


\section{Diğer Kaynaklar}

"Adverse Events in Robotic Surgery: A Retrospective Study of 14 Years of FDA Data", 2016, https://www.ncbi.nlm.nih.gov/pmc/articles/PMC4838256/ (Erişim Tarihi: 12.11.2020).

"AI technology and government decision making -recent Italian rulings", 29.06.2020, https://iclg.com/ibr/articles/10731-ai-technology-and-professional-decision-makingrecent-italian-rulings (Erişim Tarihi: 12.11.2020).

Asociacion de Funcionarios y Abogados por los Derechos de los Animales y Otros Contra Gcba Sobre Amparo, Expte. A2174-2015/0, 21.10.2015, https://ijudicial.gob.ar/wpcontent/uploads/2015/10/Sentencia-Orangutana.pdf (Erişim Tarihi: 12.11.2020).

"Beijing Internet Court Launches AI Judge", http://www.xinhuanet.com/english/2019$\underline{06 / 27 / \mathrm{c} 138178826 . h t m}$ (Erişim Tarihi: 12.11.2020).

$\begin{array}{lllll}\text { Civil Liability } & \text { Regime } & \text { For } & \text { Artificial } & \text { Intelligence, }\end{array}$ https://www.europarl.europa.eu/doceo/document/TA-9-2020-0276_EN.html (Erişim Tarihi: 15.05.2021).

Constitución

Del Ecuador, https://www.ilo.org/dyn/natlex/docs/SERIAL/82263/89945/F253880992/Constitucion\%2 0de\%20Ecuador\%202008.pdf (Erişim Tarihi: 12.11.2020).

Dijital Dönüşüm Ofisi, Türk Beyin Projesi (TBP), https://cbddo.gov.tr/projeler/tbp/ (Erişim Tarihi: 12.11.2020).

euRobotics, The European Robotics Coordination Action, Suggestion for a Green Paper on Legal Issues in Robotics, 2012, https://www.unipv-lawtech.eu/files/euRobotics-legalissues-in-robotics-DRAFT_6j6ryjyp.pdf (Erişim Tarihi: 12.11.2020).

Executive Office of the President National Science and Technology Council Committee on Technology, Preparing for the Future of Artificial Intelligence, 2016, https://obamawhitehouse.archives.gov/sites/default/files/whitehouse files/microsites/ostp /NSTC/preparing_for_the future_of_ai.pdf (Erişim Tarihi: 12.11.2020). 
HAWKING, Stephen, "Science AMA Series: Stephen Hawking AMA Answers", 2015, https://www.reddit.com/r/science/comments/3nyn5i/science ama series stephen hawkin g_ama_answers (Erişim Tarihi: 12.11.2020).

High Court of Uttarakhand, Salim v. State of Uttarakhand, Writ Petition (PIL) No.126 of 2014, 20.03.2017, https://www.nonhumanrights.org/content/uploads/WPPIL-126-14.pdf(Erişim Tarihi: 12.11.2020).

İstanbul Üniversitesi, "Robotik Cerrahi Cihazı 'Da Vinci' Yara İzi Bırakmıyor”, https://www.istanbul.edu.tr/tr/haber/robotik-cerrahi-cihazi-da-vinci-yara-izi-birakmiyor4D0077006C0069007A005600360071007000570049003100 (Erişim Tarihi: 12.11.2020).

"Meet the First-Ever Robot Citizen - A Humanoid Named Sophia that Once Said it Would 'Destroy Humans' ", Business Insider, 27.10.2017, https://www.businessinsider.com/meet-the-first-robot-citizen-sophia-animatronichumanoid-2017-10?r=UK (Erişim Tarihi: 12.11.2020).

Nevada Revised Status Chapter 4822-Autonomous Vehicles, https://www.leg.state.nv.us/nrs/nrs482a.html (Erişim Tarihi: 12.11.2020).

Non-Paper - Innovative and Trustworthy AI: Two Sides of the Same Coin, Position paper on behalf of Denmark, Belgium, the Czech Republic, Finland, France, Estonia, Ireland, Latvia, Luxembourg, the Netherlands, Poland, Portugal, Spain and Sweden on Innovative and Trustworthy AI, 2020, https://em.dk/media/13914/non-paper-innovative-andtrustworthy-ai-two-side-of-the-same-coin.pdf (Erişim Tarihi: 12.11.2020).

Proposal for a Regulation Laying Down Harmonised Rules on Artificial İntelligence (Artificial Intelligence Act), https://digital-strategy.ec.europa.eu/en/library/proposal$\underline{\text { regulation-laying-down-harmonised-rules-artificial-intelligence-artificial-intelligence }}$ (Erişim Tarihi: 15.11.2021).

Report with Recommendations to The Commission on Civil Law Rules on Robotics, 2015/2103 (INL), $\quad$ https://www.europarl.europa.eu/doceo/document/A-8-20170005 EN.html?redirect (Erişim Tarihi: 12.11.2020). 
ROSEN, Charles/NILSSON, Nils/RAPHAEL, Bertram, "Shakey", Life, 1967, http://cyberneticzoo.com/cyberneticanimals/1967-shakey-charles-rosen-nils-nilssonbertram-raphael-et-al-american/ (Erişim Tarihi: 12.11.2020).

Te Awa Tupua (Whanganui River Claims Settlement) Act 2017, Public Act 2017, No. 7, 20.03.2017, $\quad$ http://www.legislation.govt.nz/act/public/2017/0007/latest/whole.html (Erişim Tarihi: 12.11.2020).

“Tesla's 'Autopilot' Shares Blame in 2016 Fatal Crash, U.S. Investigators Say”, The Wall Street Journal, 12.09.2017, https://www.wsj.com/articles/teslas-autopilot-shares-blame-in2016-fatal-crash-u-s-investigators-say-1505233891 (Erişim Tarihi: 14.05.2021).

"Two Die in Tesla Car Crash in Texas with 'No One' in Driver's Deat, Police Day", The Guardian, 19.04.2021, https://www.theguardian.com/technology/2021/apr/19/two-die-intesla-crash-no-one-in-drivers-seat-police (Erişim Tarihi: 09.05.2021).

“Uber 'Not Criminally Liable' for Self-Driving Death", BBC, https://www.bbc.com/news/technology-47468391 (Erişim Tarihi: 12.11.2020).

White Paper, On Artificial Intelligence - A European Approach to Excellence and Trust, https://ec.europa.eu/info/sites/info/files/commission-white-paper-artificial-intelligencefeb2020 en.pdf (Erişim Tarihi: 12.11.2020). 